\title{
Weissenhof ve Kochenhof Stuttgart Yerleşkelerinin Deutscher Werkbund'un Misyonu Özelinde Tarihsellik Bağlamında Okunması
}

\author{
Aslı CAN ${ }^{1}$
}

Öz

Weissenhof ve Kochenhof Stuttgart Yerleşkelerinin Deutscher Werknund'un Misyonu Özelinde Tarihsellik Bağlamında Okunması adlı makale, Deutscher Werkbund kuruluşunun kendine biçtiği misyonlar bağlamında bir mimarlık manifestosu olarak güçlü alt metinleriyle birlikte üretilen, Weissenhof yerleşkesinin, onun antitezi olarak sunulan Kochenhof yerleşkesinin de dikkate alınarak okunmasını amaçlar. Mimarlık tarih yazımında ikili karşıtık nesneleri olarak anlatılagelen bu iki yerleşkenin şifreleri, politik ve sosyal arka planları, ideolojik tandansları ve çoğulluk ya da aynılık barındıran morfolojileri bağlamında çözülmeye çalışılır. Bu sebeple önce Almanya'nın mimarlık üretimini kavramsallaştırarak misyonunu belirleyen Deutscher Werkbund kuruluşunun yapısı incelenir. Söz konusu kuruluşun strüktürü ve aktörleri bağlamında Birinci Dünya Savaşı öncesinden 1920'lerin sonuna kadar uzanan dönemin tasarım manifestolarına dair bilgiler verilir. Ardından önce metnin temelini oluşturan Weissenhof yerleşkesinin ortaya çıkış dinamikleri incelenir. Ardından Kochenhof yerleşkesinin misyoner tandansları yine dönemin aktörleri ve politik eğilimleri bağlamında okunmaya çalışıır. Makale bir yandan içine aldığı dönemde Almanya'nın mimari üretim ve pratiklerini açıklığa kavuşturmaya çalışırken diğer yandan politik ve kültürel arka planına dair önemli bir hikaye ortaya koyan iki yerleşkenin morfolojik ve ideolojik özelliklerini ortaya koyar.

Anahtar Kelimeler: Yerleşke, Modernizm, Stuttgart, Manifesto

\section{A Historical Reading on Weissenhof and Kochenhof Settlements on Behalf of Deutscher Werkbund's Mission}

\begin{abstract}
\footnotetext{
${ }^{1}$ Yeditepe Üniversitesi, Mimarlık Fakültesi, Mimarlık Bölümüi, İstanbul

*ilgili yazar/Corresponding author: nevinasli.c@gmail.com

Gönderim Tarihi / Received Date: 19.04.2021

Kabul Tarihi / Accepted Date: 23.08.2021
}

The article titled A Historical Reading on Weissenhof and Kochenhof Settlements on Behalf of Deutscher Werkbund's Mission aims to read the Weissenhof settlement, which is presented as an architectural manifesto in the context of the missions that Deutscher Werkbund has set itself wiyhin the context of a dichotomy defined by the Kochenhof settlement. The codes of these two settlements, which have been described as objects of binary opposition in architectural historiography, are tried to be resolved in the context of their political and social backgrounds, ideological conventions, and morphologies that include plurality or sameness. For this reason, the structure of the Deutscher Werkbund foundation, which determines its mission by conceptualizing Germany's architectural production, is examined first. In the context of the structure and actors of the organization in question, information is given on the design manifestos of the period from before the First World War to the end of the 1920s. Then, the emergence dynamics of the Weissenhof settlement, which forms the basis of the text, are analyzed first. Then, the missionary fantasies of the Kochenhof campus are tried to be read in the context of the actors and political tendencies of the period. The article tries to clarify the architectural 
production and practices of Germany in the period it covers, on the other hand, it reveals the morphological and ideological characteristics of the two dettlements that reveal an important story about their political and cultural background.

Keywords: Settlement, Modernism, Stuttgart, Manifestation

\section{Giriş}

Weissenhofsiedlung Stuttgart'a günümüze kadar gelen mimarlık tarihi yazımı bağlamında bakmaya çalıştığımızda karşımıza çıkan, söz konusu yerleşkenin basit bir konutlar bütünü olmanın çok ötesinde bir anlama sahip olduğudur. Yerleşkenin tasarlanması ve ortaya konması bir manifesto olarak ele alınmıştır. "Yeni zamanın konutu"nun ne olduğunu tanımlamanın ötesinde, söz konusu zamanda nasıl yaşanması gerektiğini de deklare etmek isteyen Deutscher Werkbund sergisi "die Wohnung", mimarlık tarihi dahilinde, özellikle "Uluslararası Üslup"tan söz edilmekteyken, başka bir deyişle "modernist" mimarlığın temellerinin atılışı konu edildiğinde çok önemli bir yerde durmaktadır.

Weissenhofsiedlung'a zamanında atfedilen önem ve yerleşkenin ilk modernist konut örnekleri bütünü olarak algılanmak suretiyle tarih yazımında kendine yer edinmesi Giedion tarafından ortaya konmuş "Weissenhofsiedlung Stuttgart yerleşkesi, iki büyük değişimin kanıtıdır: el yapımı metotlardan sanayileşmiş konstrüksiyonlara geçiş ve yeni bir yaşam biçiminin önsezisi," tanımı üzerinden rahatlıkla okunabilir (Giedion, 2008, s. 547).

"Bu çalışma, 1927 yılında Deutscher Werkbund [DW] tarafından Stuttgart'ta açılan "Die Wohnung" isimli sergi kapsamında inşa edilen numune yerleşke olan Weissenhofsiedlung Stuttgart'ın, tarih yazımında muhtelif bir dikotomi olarak kabul edilen antitezi Kochenhofsiedlung ile birlikte dönemin kültürel pratikleri, yaygın ideolojileri bağlamında düşünsel ve biçimsel bir analizini yapmaya çalışmaktadır.

\section{Deutscher Werkbund}

Herrmann Muthesius, DW'nin misyonunu “Kurucuları, tatbiki Alman sanatının rütbesinin yükseltilmesinin; çalışmaya onurunu geri vermenin ve yeni çağın ruhu ile uyum yakalayacak ahenkli bir üslup geliştirmenin; endüstrinin ilerici güçleri ile birlikte mümkün olduğunu kanıtlamak istiyorlardı," şeklinde anlatır. DW'nin amacı, Almanya'nın ulusal arenadaki duruşunu değiştirmek, ülkeyi hak ettiği tasarım anlayışına kavuşturmak ve "koltuk yastığından şehir planına kadar" ortaya çıkması gereken kusursuz uyumu sağlamak için yeni bir tasarım anlayışı ortaya çıkarmaktır (Maciuika, 2009, s. 67-79).

5 - 6 Ekim 1907'de Münih'te yapılan genel toplantı ile birlikte yaklaşık 100 sanatçı, iş insanı, sanat dostu bir araya gelir. Theodor Fischer başkanlığında yapılan toplantının amacının "ahenkli kültürün yeniden ortaya çıkarılması" olduğu telaffuz edilirken, görevinin ise "Alman tüketim ürünlerinin form ve kalitelerinin düzeltilmesi" olduğu söylenir. DW böylece, 1907 yılında, Theodor Fischer başkanlığında tarih sahnesine ilk adımızı atar (Schwartz, 1996, s. 12).

Sanatla endüstriyel üretimin uyumlu birlikteliğini inşa etme çabasını güden DW'nin öncülüğünü yaptığı en büyük kabullerden biri, eskiden ayrı ayrı zanaat kolları tarafından temsil edilen kullanım nesnelerinin artık bir bütün olarak değerlendirilmesidir. Toplantıda kabul edilen tasarım anlayışı bağlamında tüm nesneler için geçerli olacak tasarım ve 
biçim ilkelerinin binaya da uygulanması, mimarı geleneksel kimliğinden çıkarıp tasarımcı kimliğine dönüştürmüştür. (Schwartz, 1996, s. 1-8).

Dönemin Almanya'sındaki tasarım ve mimarlık ortamının önde gelen simaları arasında yer alan katılımcıların düşünce yapılarının, kısa bir zaman içerisinde farklı ekol ve anlayışlar doğrultusunda evrileceği, yenilen Almanya'yı yeniden inşa etmek için farklı yaklaşımlar benimseyecekleri bilinmektedir. Ancak bu kayma sırasında DW'nin Almanya'nın mimarlığını tanımlamak için kullandığı ve mimarlık alanında bir döneme damgasını vuracak olan "Neues Bauen" ve devamında aslında biraz da Almanya'nın gücünü küreselleştirme isteğini de açıkça anlatan ve kültürel sömürgeciliğin bir özlemi dahilinde isimlendirilen "Enternasyonel Üslup" öne çıktıkça DW'nin klasisist-gelenekselci ve sonrasında milliyetçi olarak sıfatlandırılabilecek isimlerin erozyonuna uğradığı muhakkaktır.

DW'yi daha yakından tanıyabilmek adına, kuruluş bağlamındaki üç büyük isim olarak Hermann Muthesius, Friedrich Naumann ve Henry van de Velde'den söz etmek gerekir.

Muthesius, iç mimarlık alanında dönemde yavaş yavaş kendini belli eden reform hareketinin, mimarlığın yeniden tanımlanmasına yol açacağını ve tüm sanatları etkisi altına alacağını düşünmektedir. Neuman, Muthesius'un fikirlerini paylaşıyor gibi gözükmektedir, lakin önüne koyduğu hedef daha büyüktür. Spesifik ürünler üzerinden söz söylerken ortaya koymaya çalıştığı ve herkesi ikna etmek için uğraştığı kavram, topyekûn bir Kültür Reformu'nu işaret eder. Henry van de Velde'nin konumlanışı, modernitenin ortaya çıkardığı açılımların insan odaklı doğasına daha yakın düşmekte ve diğer isimlerin fikirlerinden ayrışmaktadır. Van de Velde, kuruluşun sanatçıya kişi özelinde imkanlar sağlaması, bu şekilde önünü açması ve yapıt ve üretimlerine yansıyan bireyselliği ön plana çıkarmasına yardımcı olması gerektiğini savunmaktadır (Maciuika, 2009, s. 67-79).

1908 - 1914 arasındaki dönem, DW'nin ana prensiplerinin ve eylem programının oluştuğu aralık olarak kabul edilir. Form anlayışı ve zevkin doğası üzerinde mümkün olduğunca fazla etki bırakmaya dayalı bir misyonla ortaya çıkan DW'nin en önemli hedeflerinden biri, Almanya'ya mal edilecek yeni üslubun kalitesini oluşturmaktır. Sonuna doğru, bünyesindeki çok sesliliğin kaçınılmaz olarak keskin ayrışmalara dönüşeceği periyotta gerçekleştirilen 1914 kongresi, DW'nin gelecekteki yaklaşımını netleştirmesi bağlamında, 20. yüzyıın Alman mimarisi ve tasarımının, daha sonraki dönemler üzerinde önemli etkiler yaratmış bir dönüm noktasına tanıklık eder. $3-5$ Temmuz 1914 tarihlerinde, Mayıs - Ekim arasında Köln'de düzenlenen ilk DW sergisi sırasında düzenlenen kuruluşun yıllık toplantısı, Muthesius ve van de Velde'yi geri dönüşü olmayacak şekilde karşı karşıya getirecektir.

7 yılını doldurmuş ve artık yerini büyük ölçüde sağlamlaştırmış olan DW, o yıl ilk sergisini gerçekleştirir. 1908'de Peter Behrens tarafından tasarlanmış olan AEG fabrikasının yanı sıra sergide yer alan Van de Velde'nin Werkbund Tiyatrosu ve Bruno Taut'un Cam Ev'i, DW'nin simgesel yapıları arasında yerlerini alırlar. "İşlevsel olmayan güzel olamaz" savı doğrultusunda tasarımlarını ortaya koyan DW aktörleri, savaşın hemen arifesinde açılan bu sergi bağlamında oturtmaya çalıştıkları tasarım anlayışını üç boyutlu mekanlar olarak ortaya koyarlar.

Sergi esnasında Köln'de yapılan yıllık toplantıda dile getirdiği üzere Muthesius, iddialı bir dille kaleme alınmış olan on kılavuz ilkede [Leitsaetze], kuruluşun ve üyelerinin izlemesi gerektiğini düşündüğü net bir güzergâh çizer: Bundan böyle mimaride, endüstride ve uygulamalı sanatlarda oluşturulacak standardize edilmiş "tipler", Alman imalatçılarının 
tüketim ve ihraç malları üretiminde ciddi bir artış sağlayacaktır. Bu, Almanya'nın ekonomik refah düzeyini yükseltip uluslararası alandaki gücünü artırmakla kalmayacak, küresel ticaret sahasında bütünleşmiş, kendi bilincinde olan ve niteliksel olarak üstün bir "Alman Üslubu" da yaratacaktır. Yani DW'ye üye olan Bayer, Daimler, Benz ve Bosch gibi şirketler, sanatçıların, zanaatkarların, mimarların, mühendislerin ve imalatçıların aralarında geliştirecekleri yeni iş birliğinden istifade edeceklerdir. Buna karşılık Henry van de Velde, DW sanatçılarının mutlak özgürlük haklarını savunur. Van de Velde ve kendisine destek olan Walter Gropius ve Karl Ernst Osthaus gibi üyeler, DW'nin kendisini büyük hacimli, yüksek nitelikli, endüstri odaklı "tipler" yaratmaya vakfetmesi halinde, bu özgürlüğün ayaklar altına alınacağını düşünmektedirler (Maciuika, 2009, s. 67-79).

Dönemin Almanyası'nın politik durumu, DW'nin Muthesius üzerinden kendine biçtiği "Alman Üslubu" yaratma rolünü biçimlendirmekte ve kolaylaştırmaktadır. DW'nin lider kadroları ile devletin üst konumlarındaki yetkililer arasında o güne kadar kurulmamış üst düzey ilişkiler mevcuttur. Bu bağlamda bakıldığında Muthesius'un "tipleri” 20. yüzyıl başındaki işlevselci estetik ve onun modernist düşüncedeki rolü açısından mimarlık tarihi paralelinde oldukça anlamlı olmakla birlikte bundan daha fazlasını ifade eder. Söz konusu kılavuz ilkeler, özel sektörün geniş kesimlerini ve küresel ticari dağıtımı devlet güdümünde yeniden düzenleme amacı taşıyan yeni ulusal politikaların estetik çerçevesinde ifade edilmiş boyutudur.

Tüm bunlar, DW'nin, kuruluşundan, Birinci Dünya Savaşı patlak verip de Almanya'nın dünya politikasını alt üst edene kadarki süre içerisinde kendini konumlandırdığı yeni kültürel bir entelijansiya kuruluşundan çok daha fazlası olduğunun önemli göstergeleridir. DW, kendisini, sanayi devrimini İngiltere ve Fransa'nın arkasından takip eden Almanya'nın, değişen dünya ve güç odakları arasında olmak istediği yerin kültürel ve sanatsal mecrası olarak sunar. Dönemin alternatif transandantal güçleri olarak kabul edebileceğimiz ulus-devletler bağlamında, ulusalı uluslararasılaştırma arayışı içerisinde üretimlere yön vermeyi amaçlayan DW, aslında bu şekilde Almanya'nın uluslararası platformda daha fazla söz söyleme hakkı edinmesinin de bir başka sebebi olmayı amaçlamaktadır.

DW'nin bu önemli politik konumu, dönemin Alman hükümetinden oldukça fazla destek gördüğü için, Muthesius'un ilkelerine "karşıt ilkeler" ile karşılık veren ve 1914 kongresinde okuduğu bildiriyle Muthesius'un konuşmasının hemen her cümlesine itiraz eden van de Velde ve sanatta bireyselliği savunan, dolayısıyla onun endüstriyellik ve uluslararası politik çıkarlar uğruna gasp edilmesine karşı çıkan destekçileri için DW macerası sona erer. DW, bundan sonra Muthesius ilkeleri dolayımıyla kendisine biçtiği politik "toplum mühendisliği" rolü ile yoluna devam edecektir (Maciuika, 2009s. 67-79).

DW'yi özgün tarihselliği içerisinde anlamlandırma denemesinin bir sonraki adımı, DW'nin ideolojik arka planını biraz daha deşmeyi gerektirir. Bu bağlamda dönemin "Zeitgeist"ı içerisinde fazlasıyla önem atfedilen "Gesamtkustwerk" olgusunu ve paralelinde DW'nin afirme ettiği veya onaylamadığı periyodik faktörleri anlamak önemli gözüküyor.

"Gesamtkunstwerk" "Bütünlüklü Sanat Eseri" şeklinde dilimize aktarılabilir. Kavramı yakından inceleyebilmek için dönemin ruhuna ait bir toparlama yapmak hayati gözükmektedir. 20. yüzyıl başı Avrupa'sına bakıldığında karşımıza çıkan resim şu şekilde tariflenebilir: modernitenin dağıtan, yerinden eden ya da Marshall Berman'ın Marx’tan yaptığı son derece isabetli alıntıya göre "katı olan her şeyi buharlaştıran" (Berman, 2006, s. 1) doğası, kentleri ve kaçınılmaz olarak yaşam biçimlerini dönüştürmüştür. Kentler artık, geleneksel dünyanın arz ettiği biçimde tanıdık dirlik ve düzen mekanları değil; tekinsiz, muhtelif pratiklerin tesadüfler tarafından işlediği, 
transandantal katılığını bir türlü dışa vuramamış, bambaşka biçimlerin bir arada varlıklarını sürdürmeye çalıştığı yaşam alanlarıdır. Dönemin Almanca konuşan gelenekselci ve modernitenin korkutucu doğası içerisinde hayatta kalmaya çalışan düşünürlerinin metinlerinde "Heimat" [yurt], Ruhe [huzur], Ordnung [düzen], Harmonie [ahenk] ve benzeri kelimelere rastlanması bu bağlamda tesadüf değildir. Özellikle Hans Sedlmayr tarafından "Verlust der Mitte" [Merkezin Kaybı] olarak tarif edilen yeni yaşam biçiminin doğası, söz konusu kelimelerin anlamsal karşılıklarını baştan inşa etmeyi gerektirir. Bu sözcüklerin tamamı "merkez"in yeniden tanımlanmasına giden yol üzerinde karşıya çıkacak durakları tarif ederler.

"Bütünlüklü Sanat Eseri" anlatımının gücü ile, içerisinde bulunduğu dönemin "Zeitgeist"ına damgasını vuracak kavramlardan biridir. Kavram rahatlıkla dünyada her şeyin birbiriyle uyumlu bir bütün halinde olduğu yanılsamasının kayboluşuna dair sunulmuş bir reçete olarak tanımlanabilir. Adolf Loos tedavi sürecini "Tüm kültürel alışkanlıkların birbiriyle uyumlu ve ahenkli bir şekilde pratiğe dönüştürülmesi gerekir. Aynı çataldan kente her şeyi birbiriyle uyumlu tasarlamak gibi." cümleleriyle tarif eder (Loos, 2000, s. 23-45). Bu bir koruma mekanizması, dışarıdan herhangi bir "yabancı" faktörün söz konusu ahenk içinde tasarlanan "Bütünlüklü Sanat Eseri"ni bozma intimaline karşı alınmış bir önlemdir. Behrens'in hem logosu hem de içinde üretilen çaydanlığı ile birlikte tasarladığı AEG fabrikası, kavramı muazzam bir şekilde örnekler (Şekil 1).
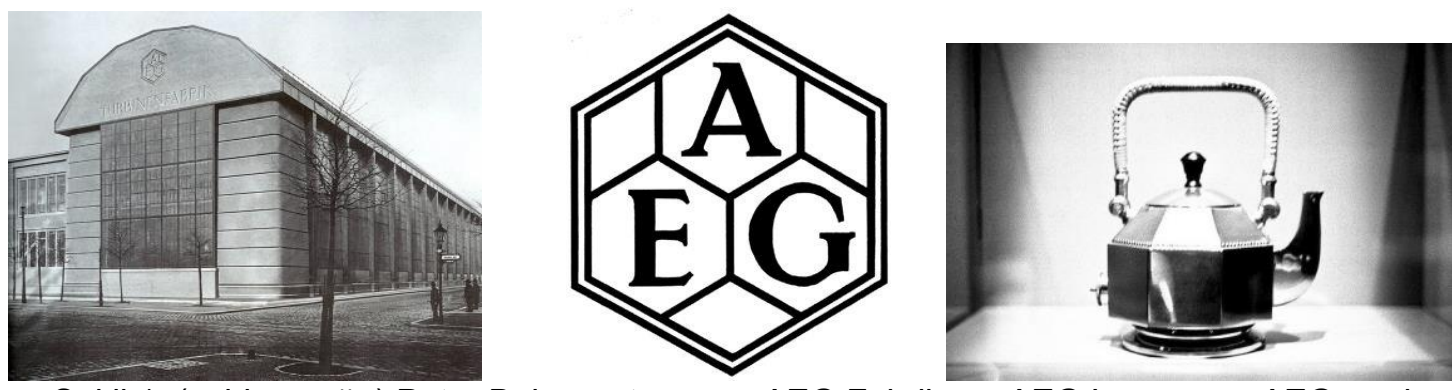

Şekil 1: (soldan sağa) Peter Behrens tasarımı AEG Fabrikası, AEG Logosu ve AEG marka çaydanlık, URL-1).

"Gesamtkustwerk", modernite ile birlikte kaybolan dirlik ve düzeni yeniden var etmeye çalışan karşı-modern anlatılardan biridir. Dağılan dünyayı toparlama, bir araya getirme ve o getirdiği yerde tutma tahayyülü ile yola çıkmak suretiyle kendisini var etmeye çalışmıştır. Dönemin birçok pratiğini meşrulaştıran, anlamlandırmamıza olanak tanıyan bu kavram, çoğaldıkça sekülerleşen karşı-modern anlatıların her biri gibi katıığını sonsuza dek sürdüremezken, kendisine dair üretilen tüm karşı ideoloji ve gerçekleştirilen uygulamalara rağmen içinde doğduğu döneme ve tüm öğretilerine damgasını vurmuştur.

"Gesamtkunstwerk" özellikle DW üzerinden bir defa daha okunduğunda karşımıza çıkan tablo şaşırtıcı değildir: DW'nin, Muthesius üzerinden kendisine çizdiği yol, "tipler" ve genel-geçer bir "Alman Üslubu"nu yaratma olgularıyla bütünleşerek sanat ve endüstriyel üretimin dağılmamak üzere derlenip toparlanması amacını içinde barındırmaktadır. Van de Velde ve "sanatsal üretimin bireyselliği" doğuracağı muhtemel çokluklar göz önüne alındığında, DW'nin söz konusu amaç ekseni ve ideolojisi doğrultusunda, kuruluş içinde uzun soluklu bir etkisi olması çok da olası gözükmemektedir.

DW, dönemin tüm kültürel, sanatsal ve endüstriyel pratiklerini kendi içinde toplayarak ve tüm bunları kendisini konumlandırdığı politik alan ile harmanlayarak periyodundaki en önemli, umut vaat eden ve güvenilir kuruluşu haline geldiğinde, dünyanın yerinden 
oynaması ile birlikte havaya karışmış, başıboş bir şekilde devir daim yapan sayısız kavramın varlığından söz edilebilir. DW'nin ise kendi üretim ve düşünce sistemlerinin varoluşunu afirme edebilmesi için, bunların bir kısmından faydalanmaya intiyacı olacaktır. DW kendisini kaçınılmaz olarak bazılarının yanında, bazılarının ise karşısında konumlandırır, zira söz konusu mecralar çokluklarının yanında başka ideolojik ve pratik örüntüler ile bir arada var olabildikleri için, DW'nin toparlayıcılığı açısından tehlike arz etmeleri oldukça mümkündür.

Genel başlıklar altında toparlarsak, DW üyelerinin özellikle hoşlanmadıkları kavramların kapitalizm ve dolayısıyla sanayi devrimi ile ilişkilendiklerini gözlemlemek mümkündür. Bu da elbette şaşııtıcı değildir, zira dünyanın dengesini alt üst eden, "başları ayak, ayakları baş" yapan, toplumsal yapının tepetaklak olmasına sebebiyet veren ve dolayısıyla modernite rüzgarının esmeye başlamasına yol açan sanayi devrimi güdümlü kapitalizmin ta kendisidir. Değiştirdiği dünyayı kontrol altına almak ve değişimin kontrolden çıkmasını engellemek adına aldığı tüm önlemlere rağmen kapitalizm, özel sektör yatırımlarını şiddetle ulus-devlet üzerinden tanımlamaya ve üretim pratiklerini baştan tek bir devlet mekanizmasıyla bu şekilde kurgulamaya çalışan DW'ye yaranamaz. Moda, ticareti, empresyonizm, reklamcılık, keyfiyet, hareketlilik, manipülasyon, çatışma, pazar, arzu, taklit, varyasyon ve benzeri, kapitalizm ile doğrudan ilişkilendirilebilecek kavramlar, DW'nin kara listesinde yer alır. Bu kavramlara yakından bakılınca, hemen hepsinin rastlantısallığa ve katmanlaşmaya yol açan muhtelif dönüşüm potansiyelleri barındırdığı tespit edilebilir. Dolayısıyla DW'nin "Gesamtkunstwerk" anlayışı tehlikeye girme intimaliyle karşı karşıya kalır. Bu, DW'nin, söz konusu kavramları yerinden etmek ve yerine yerlerini koymak suretiyle düzeni yeniden oluşturmak istemesi hiç de şaşırtıcı değildir (Schwartz, 1996, s. 38-39).

DW, çözücü tüm kavramların karşısına, bağlayıcılık yaratma tandanslı kavramlar yerleştirir. Üslup, tip, bütünsellik, Grossbetrieb [büyük şirket], kimlik, kalite, merkez, nesnel, yasa, soylulaştırma ve içirilme bunlar arasında sayılabilir. Söz konusu olguları mimari, sanatsal ve endüstriyel üretimin kalbine yerleştiren DW, böylelikle hemen hepsiyle bütünleşme stratejisini benimsemekte ve kendi ütopyasını hayata geçirmeye çalışmaktadır (Schwartz, 1996, s. 39).

Savaş, kaçınılmaz olarak her şeyi değiştirir. Dönüşen ve dağılan dünyanın ilk büyük savaşı, belki de bu dağılmanın sonucunda yerinden edilen her şeyin bir çeşit yerine oturtulma çabası olan Birinci Dünya Savaşı da doğal olarak Almanya'nın her alandaki tüm içsel dinamiklerini yerle bir eder. Almanya'nın politik duruşuyla kendisini yan yana konumlandırmış olan DW ise kaçınılmaz olarak bu durumdan etkilenir, üstüne üstlük savaş sonrasında ülkenin yeniden inşasına yine aynı "toplum mühendisliği" misyonuyla kendisine çok önemli bir rol atfeder. DW, savaş sonrası kendisini bambaşka bir konumda bulur.

Birinci Dünya Savaşı, 1914 yılına, yani 20. yüzyılın ilk çeyreğine tarihlenir. 19. yüzyıl kaotizmi bu dönemde Avrupa'yı tam anlamıyla etkisi altına almıştır. Monarşiler yerlerini ulus-devletlere bırakmakta, geleneksel üretim ve yönetim biçimleri tarihe karışmakta, sanayi devrimi bir süreç olmaktan çıkıp kalıcı bir faktör olarak kendi gerçekliğini yaratmaktadır. İşte bu darmadağın resmin içinde kaçınılmaz olarak ortaya çıkan savaş bittiğinde, beklenenin aksine hiçbir şey yerine oturtulmamış, dağınıklık toparlanmamıştır.

\section{Weissenhofsiedlung Stuttgart}

"Bir Mimarlığa Doğru" isimli "modernist konut manifestosu" niteliğindeki kitabını adeta bir peygamber refleksiyle yazmış olan Le Corbusier, eserin 1924 tarihli ikinci baskısının 
önsözünde kurduğu ve birebir alıntıladığımız şu cümlelerle; mimarın geçirdiği tarihsel rol değişimini ve bu değişimin bilinçli farkındalığını açıkça ortaya koyar:

"Mimarın görevi, belirleyici dönüm noktalarında toplumun ortak düşüncesini bir adım daha ilerletmek için itici bir güç olmaya çalışmaktır. Böylece mimarlık zamanın aynasına dönüşür. Günümüz mimarlığı konutla; sıradan ve çağdaş insan için sıradan ve çağa uygun konutla ilgileniyor. Artık saraylarla uğraşmıyor. İşte zamanın bir göstergesi. Sıradan insan için 'herkes için' konut araştırması yapmak demek, insana özgü temel ilkeleri, insan ölçeğini, gereksinimini karşıllayan tipi, işleve yönelik tipi, duyarlı tipi yeniden bulmak demektir. İşte işin en önemli noktası ve tamamı budur. İnsanlığın şatafatı terk ettiği onurlu çağ kendini göstermekte," (Le Corbusier, 2005, s. 83-84).

Bu cümlelerde "yeni çağ mimarlığı" anlayışına, bu anlayışın "çağın ruhuna" [Zeitgeist] uygun ve onunla ahenk içinde olması gerektiğine dair çok fazla ipucu var olmakla birlikte, bakılması gereken en önemli nokta, mimarın konumunun, görevinin hangi doğrultuda değiştiği ve bu değişimin uygulamalarda nasıl karşılık bulduğudur. Bu değişimi daha iyi okuyabilmek adına, Almanya'nın Birinci Dünya Savaşı sonrası karşı karşıya kaldığı konut intiyacının yol açı̆̆̆ı ve acil çözüm bekleyen soruna daha yakından bakmamız gerekir.

Savaştan yenik çıkan bir ülke olmasının yanında, kentlerinin kırsaldan göç alması, yani değişen zamanın Sanayi Devrimi'nin kıta Avrupa'sındaki karşılığı aracılığıyla beraberinde getirdiği kentsel tüm olgular Almanya için de geçerlidir. Artık kentlerde tanımsız, isimsiz ve birçok kaynağa göre tekinsiz olarak tanımlanan kitleler yaşamaktadır, dolayısıyla kentler hem morfolojik hem de demografik değişimler geçirmektedirler. Bunun üzerine bir de savaştan yenik olarak çıkmanın yükü eklenince Almanya'yı yeniden "inşa etmek", "inşa" kelimesinin metaforik anlamına yapılan bir vurgu olarak kabul edilebilir. DW, tam da bu bağlamda, yeni Almanya'yı inşa etme, başka bir deyişle Alman kimliğini yeniden oluşturma ve sonrasında bu kimliğin varlığını uluslararası platformda kabul edilir hale getirme çabasına girer. Tam da bu noktada mimarların, toplumsal değişime paralel olarak değişen rolleri devreye girer; yukarında sözünü ettiğimiz üzere artık mimardan söz etmek bir toplum mühendisinden söz etmek anlamına gelecektir.

Birinci Dünya Savaşı'nın, dünyanın artık eskiye dönemeyecek şekilde değişmesine yol açması ile birlikte, dönem mimarlarının, üzerinden konuştuğumuz Almanya coğrafyasında yapı yapmaya başka anlamlar yüklemeye başladıkları bir gerçektir. Mimarların hizmet etmekle "yükümlü" oldukları profilin, saray/aristokrat çevresinden ayrıştığı; eskiden köyde ya da küçük kasabalarda yaşayıp, Sanayi Devrimi ile birlikte kentlere göç etmiş insan kitlesine dönüştüğünü vurgulamak bu noktada çok önemlidir. Ancak dikkat edilmesi gereken, söz konusu kitlenin birebir müşteri konumunda olmadığı, mimarlardan herhangi bir şey talep etmenin çok uzağında, aslında yalnızca bir sosyal sorumluluk projesi olarak var olduğu gerçeğidir. Dolayısıyla, savaş sonrası yeniden yapılanma döneminin kültürel entelijansiyası içinde oldukça üst basamaklarda oturan mimarlar; bu isimsiz, tanımsız ve aidiyetsiz kitle için yalnızca konut yapmakla kalmayacak, onların yaşam biçimini yeniden tanımlayacaklardır.

$\mathrm{Bu}$, sosyal bağlamda yeterince güçlü olan değişim, aynı zamanda büyük bir epistemolojik farklılığın da habercisidir. Artık yaşam biçimleri sosyal statü basamakları aracılığıyla düzenlenmemektedir, toplumsal sınıflar birbirine eklemlenmiş ve katmanlaşmıştır ve yaşama biçimleri ile ilgili kendilerinde söz hakkı görenler, kültürel çevrelerin önemli aktörlerinin, yani sanatçıların, mimarların ve üreticilerin dışında aynı zamanda bürokratlardır. Toplumsal düzenin uğradığı köklü değişimin kanıtı olan bu 
durum, aynı zamanda "yeni çağın" yönetim ilişkilerini belirleyen oldukça önemli bir faktör olarak ortaya çıkmaktadır.

Bu durumu yeni bir ahlak vaazı olarak yorumlamak mümkündür. Öyle ki mimarlar, kendilerine yol gösterecek olan diğer muhtelif kültürel aracılar ile birlikte değişimin önünü açmaya çalışmaktadırlar. Bu, modernitenin savurup yerle bir ettiği her unsuru, yeni zamanın, yine onlar tarafından koyulan kurallara göre toplama çabasıdır.

"Merkezi Almanya'da olan öncü [avant-garde] sanatçılar grubu, Avrupa'da o zamana değin rastlanmamış canlılıkta tartışmalara, değişik yaklaşımlara yol açan son derece yaratıcı, deneysel ve gelecekçi bir dönem yaratmışlardı. Çok dağınık olmakla beraber, geçiş dönemi sancılı ancak verimliydi. Le Corbusier'nin Bir Mimarlığa Doğru kitabı ile ondan bir yıl sonra yayımlanan ve birlikte bir bütün oluşturan Urbanisme [Kentbilim] ve L'Art Decoratif D'Aujourd'hui [Günümüzde Dekoratif Sanatlar] isimli kitapları bu dağınıklığın toparlanmasına büyük ölçüde yardım etti," (Merzi, 2005, s. 12).

Bu alıntıda sözü edilen "öncü sanatçılar grubu" rahatıkla DW ve çevresi olarak anlaşılabilir. Bu bağlamda, DW ve onun etrafında konumlanan ve farklı aktörlerden oluşan kültürel entelijansiyanın, yeni dönemin ruhu ve mimarlık anlayışını özenle çalıştığı ve ortaya çıkardığı söylenebilir.

Mimarın rolünün basit bir figüran sanatçıdan toplum mühendisi olmaya doğru evrilme sürecinin arkasında aslında çok önemli bir diğer faktör daha yatar: mimarlar /ya da sanatçılar, veya kültürel entelijansiya) yeni çağın yaşama alanlarını tasarlar ve yaşama biçimini belirlerken, asıl amaçlanan yeni çağın ruhunu tanımlama, biçimlendirme çabası, serbest akışkanlar olarak dolaşıma geçmiş olan geleneksel dünyanın donuk farklılıklarının, yeni bir biçimsel aritmeti altında eşleştirilme ve mümkün olduğunca ortadan kaldırılma denemesidir. DW oluşumu da tamı tamına bunu amaçlamakta ve bu süreç, yine Giedion'dan aşağıda alıntıladığımız gibi, mimarın rolünün değişim sürecine tanıklık etmekte ve aynı zamanda mimarlık mesleğinin hedefinde, iktidarın ta kendisi olacak şekilde yüceltmektedir: "Werkbund dönemi, Almanya'daki mimarların durumunda köklü bir değişime tanıklık etmiştir [...] Mimarın, kendi zamanının ruhunu biçimlendirmede bir rolünün olduğu onaylandı," (Giedion, 1940, s. 598).

Mimarlık kendisini geleneksel dünyanın yerle bir edilmiş en önemli değerlerinden birinin, aşkınlığın göbeğinde bulur öyle ki kutsallığı yavaş yavaş eksilen tüm olgular [aristokrasi, tanrı, din], toplum ve zamanın tinini belirleme rolünü mimarlık ve sanat çevresine devretmiştir. Bu, DW'nin, daha önce sözünü ettiğimiz, Alman kültürel pratiğinin bir huzur ve düzen içerisinde inşası hayaliyle oldukça uyumludur. Weissenhofsiedlung Stuttgart da (Şekil 2) bu hayalin bir parçası olarak şekillenecektir. 


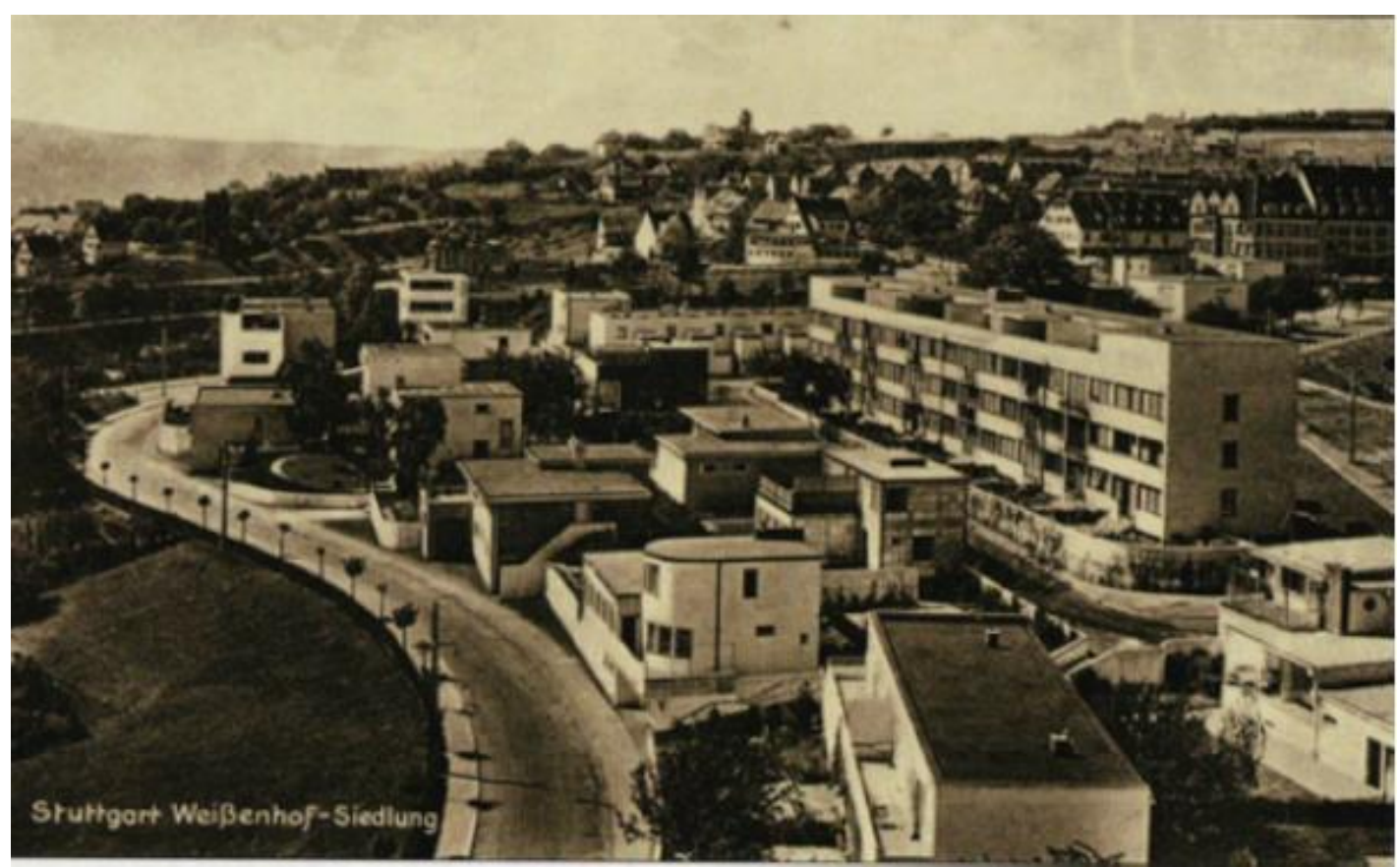

Şekil 2: Weissenhofsiedlung Stuttgart (Ulmer ve Kurz, 2006, s. 222).

Württemberg'in politik ve ekonomik durumu, savaştan sonra ülkenin geri kalanına göre çok daha çabuk normalleşir. İnşaat sektörü de aynı doğrultuda kendini büyük bir hızla toparlar. 1919 'da yeni yapılacak Siedlung inşaatlarını kolaylaştıracak bir yasa; hızla çok sayıda konut üretmeyi imkanlı kılmak suretiyle yürürlüğe sokulur. 1919 ile 1927 arasında Stuttgart'ta yalnızca 2000'e yakın konut üretilirken, bu sayı, 1932 yılına gelindiğinde 18.730'a ulaşır (UImer ve Kurz, 2006, s. 11-18).

Weissenhofsiedlung Stuttgart'ın inşası fikri, dönemin genç ve önde gelen mimar ve sanatçılarına aittir. Bu isimler arasında Richard Döcker, Richard Herre, Hugo Keuerleber, Willi Baumeister ve dönemin ünlü gazetecilerinden Düssel öne çıkmaktadır. $\mathrm{Bu}$ isimlerin asıl amacı, dönemin konut probleminin açıklıkla tartışılabileceği bir platform yaratmaktır.

Bu bağlamda, yukarıda saydığımız isimler dışında üç çok kritik aktörden söz edilmesi gerekir: sanayici, eyalet meclisi üyesi ve DW katılımcısı Peter Bruckmann, DW Württenberg kolu yöneticisi Gustav Stotz ve Stuttgart belediye başkanı Karl Lauterschlager. Bruckmann'ın genç Stuttgartlı mimarlarla kurduğu ilişki sonucunda 1925 yılında kentin incelikle planlanmasına ve diğer muhtelif inşa faaliyetleri için bir rol modeli teşkil etmesine karar verilir (Ulmer ve Kurz, 2006, s. 11-18). DW, bu planlama bağlamında bir numune yerleşke ve "yeni yapı sanatının uluslararası plan ve maketleri sergisi" fikrini öne sürer.

1926 'da söz konusu proje için yüklü bir bütçe alınır. Planlanan 1600 konutun inşa edilmesidir, bunların altmış adedi BW tarafından gerçekleştirilecektir. Amaç, modern büyük şehir vatandaşı için ucuz ve sağlıklı konut prototipleri inşa etmektir. Böylesi bir proje için en uygun yerin, Stuttgart'ın kuzeyinde bir tepe üzerine konumlanmış olan Weissenhof bölgesi olduğuna karar verilir. Misyon belirlenir belirlenmez DW, Ludwig Mies van der Rohe'yi proje yürütücülüğüne atar. Bu aynı zamanda, iki yıl sürecek ve tahmin edildiği kadar basit geçmeyecek inşa sürecinin başlangıcıdır. 
Sürecin başında Stotz ve Mies van der Rohe arasında gerçekleşen yazışmalara baktığımızda karşılaştığımız tablo, katılımcı mimarlar listesinin planlanana göre zaman içerisinde değişime uğradığı yönündedir. Yirmi altı ismin içerisinden on beşinin seçilmesinin amaçlandığını gösteren kaynaklarda, Mies van der Rohe tarafından onaylanan ikinci liste şu şekildedir (Kirsch, 1997, s. 5-13): planlanan isimler; Peter Behrens [Berlin], Le Corbusier [Paris], Richard Döcker [Stuttgart], Theo von Doesburg [Hollanda], Dr. Frank [Viyana], Walter Gropius [Dessau], Hugo Haering [Berlin], Richard Herre [Stuttgart], Ludwig Hilberseimer [Karlsruhe], Hugo Keuerleber [Stuttgart], Ferdinand Kramer [Frankfurt], Mies van der Rohe [Berlin], J. J. P. Oud [Rotterdam], Gustav Schneck [Stuttgart], Tessenow [Dresden]; yedek isimler; Otto Barting [Weimar], Alfred Gellhorn [Berlin], Arthur Korn [Breslau], W. Luckhardt [Berlin], Erich Mendelsohn [Berlin], Hanz Poelzig [Potsdam], Sigmund [Stuttgart], Stam [Zürih], Bruno Taut [Königsberg], Henry van de Velde [Brüksel], Hans Scharoun [Breslau].

Takip eden yazışmalardan, yukarıdaki isimlerin bir kısmının projeyi memnuniyetle onayladığı [örneğin Bruno Taut böylesi bir projenin önemini mektubunda defalarca vurgulayıp, katılmaktan ne kadar memnun olacağını dile getirir] (Kirsch, 1997, s. 20-23), geriye kalanların ise sözü edilen genel konut intiyaçlarından dolayı işlerinin başlarından aşkın olduğu ve teklifi üzülerek reddetmek zorunda kalacakları anlaşılır. Benzer yazışmalarla liste şekillenmeye devam ederken Peter Bruckmann tarafından ortaya başka bir fikir atılır: Weissenhofsiedlung, Stuttgart için yapılan ve bir model teşkil etmesi istenen bir projedir ve kaçınılmaz olarak Stuttgart'ın en önemli mimarlık eğitim kurumu olan Stuttgart Yüksek Okulu'nun yöneticisine de söz hakkı verilmelidir. Söz konusu yönetici, Profesör Paul Bonatz'tır. Mimar hemen yazışmalara dahil edilir. Bonatz'ın proje dahilindeki konumu, fikir babaları tarafından, proje başkanları arasında olması gerektiği şeklinde düşünülür.

Ancak işler beklenildiği gibi ilerlemez. Kendisine yapılan proje teklifinden sonra Weissenhofsiedlung için bir vaziyet planı eskizi çizen ve sonrasında bu eskizi makete dönüştüren Mies van der Rohe, 1926 yılında hem Paul Bonatz hem de Paul Schmitthenner tarafından çok ciddi bir biçimde protesto edilir. 5 Mayıs 1926 tarihinde Die Werkbundsiedlung isimli makalesi Süddeutsche Zeitung'da yer alan Paul Schmitthenner ile aynı tarihte Noch einmal die Werkbundsiedlung isimli yazısını Schwaebische Kronik'te yayımlatan Paul Bonatz, yerleşkeyi sertçe eleştirirler.

Schwaebische Kronik'te yayımlanan söz konusu yazıda Bonatz yerleşke ile ilgili şu ifadeleri kullanır:

"Weissenhof'taki Werkbund yerleşkesine baktığında insana şehir bir kâbusun içine sürükleniyormuş gibi geliyor. Bu korku, Mies van der Rohe'nin yerleşke için yaptığı ilk planı görünce daha da güçleniyor. Plan; konuyla ilgisiz, sanat değeri taşımıyor ve acemice. Çeşitli yatay açıımlar veren bir alanda, birtakım düz küpler alışılmadık bir darlık içinde yamaçta toplanıyorlar. Plan bir Stuttgart yerleşkesinden çok bir Kudüs varoşunu andırıyor," (Bonatz, 1926, s. 4) (Şekil 3). 


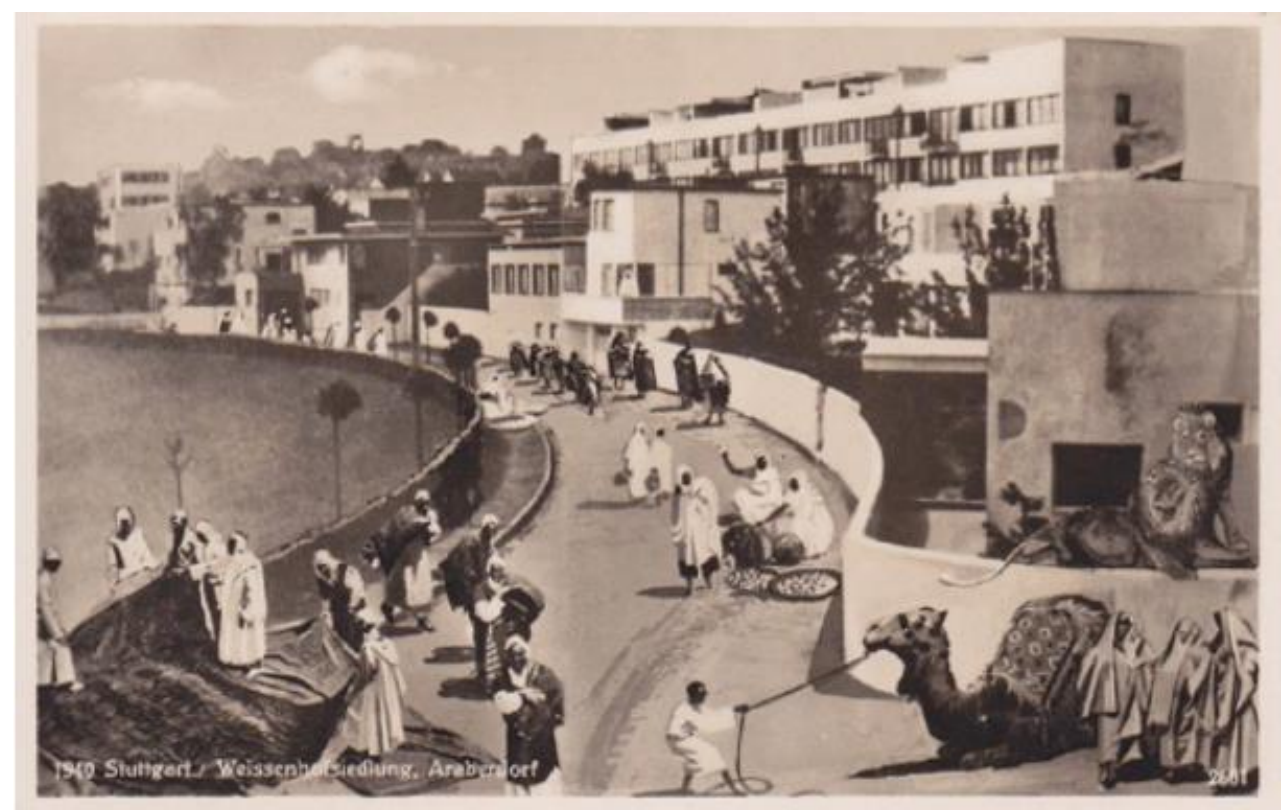

Şekil 3: Weissenhofsiedlung'u bir Arap varoşu olarak gösteren görsel (Ulmer ve Kurz, 2006, s. 205).

Aynı yazıda Bonatz, yerleşke konutlarının estetik konseptlerini "yatay çatısı ve diğer tüm kavramları ikinci, üçüncü elden Hollanda'dan alınmış formalizmler" şeklinde eleştirir. Mimar, bu sergiye karşılık olarak, Württemberg içerisinde yapılacak bir yarışma önerir. $\mathrm{Bu}$ yarışmaya katılan mimarların görevi "denenmiş, elle yapılabilecek, mantıklı ve ayakları yere basan" olgularla tasarım yapmak olacaktır (Bonatz, 1926, s. 4).

Metnin yayımlanmasının ardından iki gün sonra, yani 7 Mayıs 1926 tarihinde Bonatz tarafından, Weissenhofsiedlung'un inşaattan sorumlu yöneticisi Daniel Sigloch'a bir mektup yazılır; mektupta mimarın söz konusu yerleşkede kat'i surette yer alamayacağı özenle vurgulanır. Bonatz'a göre Stuttgart'ta konumlanacak ve ileriki yapılanmalar için örnek teşkil edecek bir yerleşke için üç mimar yeterlidir ve bu mimarlardan birinin Ludwig Mies van der Rohe olması gerekiyorsa; diğerlerinden biri, Stuttgart'ın sol kanadını temsil eden bir mimar, örneğin Richard Döcker, öteki de Stuttgart'ın sağ kanadını temsil eden bir mimar, mesel Paul Schmitthenner olmalıdır (Kirsch, 1997, s. 65).

Bu durum üzerine Mies van der Rohe, projenin mimari ve sanatsal yönetimini tek başına üstlenir (Şekil 4). Takip eden bir yıl boyunca DW, Mies van der Rohe'nin yönlendirmesiyle mimarlar listesi üzerinde çalışmaya devam eder. Adolf Loos, Henry van de Velde, Doesburg, Tessenow gibi mimarlar çeşitli nedenlerle listeden çıkarılırlar. Liste son halini 1926 yılının Kasım ayında alır: Ludwig Mies van der Rohe, Peter Oud, Gustav Schneck, Le Corbusier, Walter Gropius, Ludwig Hilberseimer, Bruno Taut, Hans Poelzig, Richard Döcker, Max Taut, Hans Scharoun, Mart Stam, Peter Behrens, Adolf Rading ve Josef Frank (Ulmer ve Kurz, 2006, s. 21). 


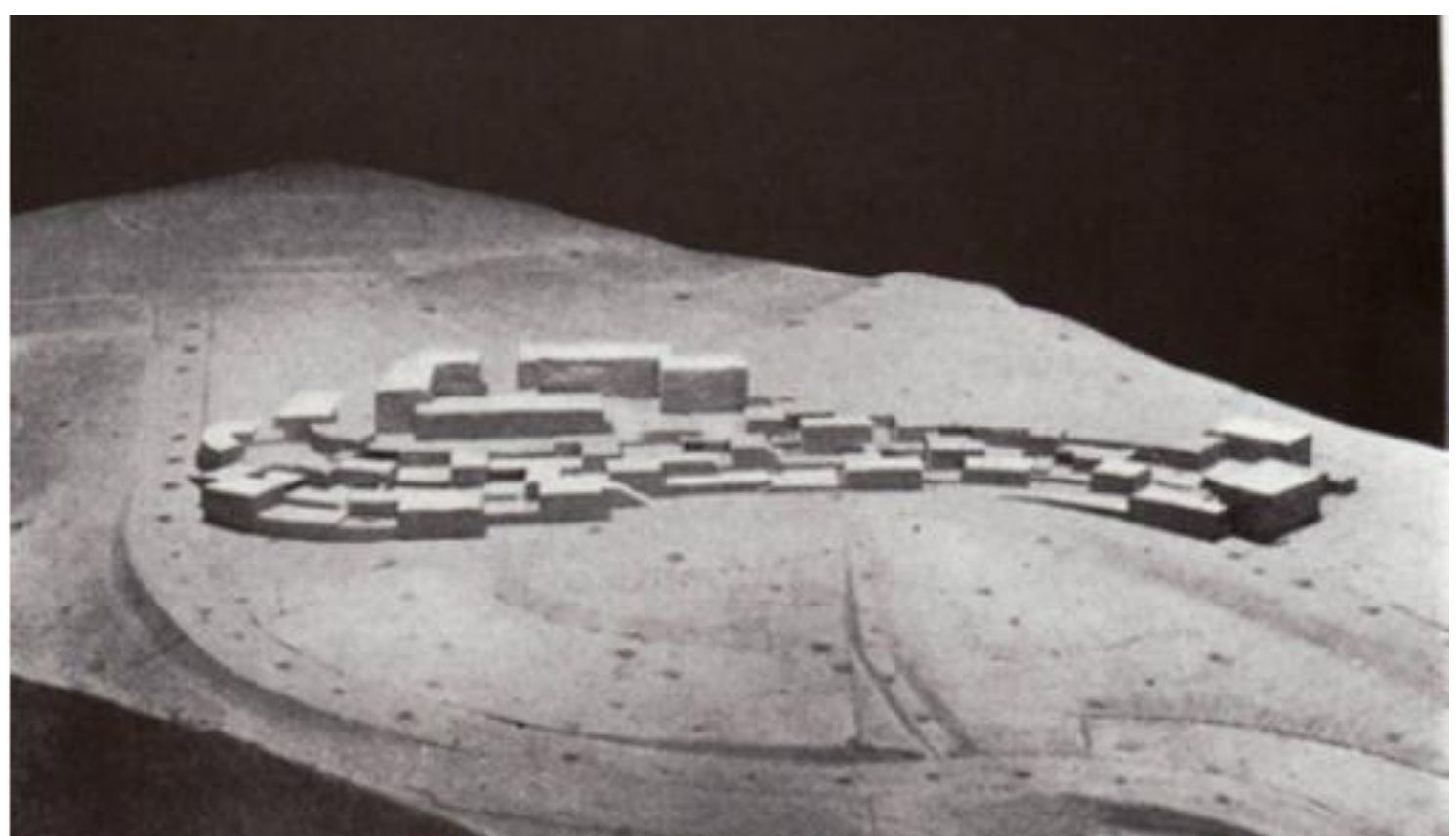

Şekil 4: Ludwig Mies van der Rohe tarafından hazırlanan yerleşke maketi (Ulmer ve Kurz, 2006, s. 21)

Victor Bourgeois bu listeye 1927 yılında dahil olur. Le Corbusier ise tasarımlarında Pierre Jeanneret ile çalışır. Richard Döcker bir süre sonra şantiye şefliğine getirilir (Ulmer ve Kurz, 2006, s. 20-23).

Söz konusu mimarların bir araya gelmesi, yerleşkenin, henüz resmi olarak telaffuz edilmemiş olsa da "Uluslararası Üslup"ta yapılacağının bir göstergesidir. Yerleşke ekonomik, insancıl ve sağlıklı konutlardan oluşacak, müşterisi "herhangi biri" olabilecektir.

Yapıların inşası kaçınılmaz olarak birtakım problemlere sahne olur. Poelzig ve Oud, bütçe analizlerini geç teslim ederler, bu durum genel bütçe ve malzeme alımında sıkıntı yaratır. Dolayısıyla bazı konutlar üç aydan kısa bir süre içerisinde inşa edilmek zorunda kalır. Kendisini yalnızca mimari ve sanatsal faktörlerden sorumlu gören Mies van der Rohe, suçu Richard Döcker'in üzerine atar. Mimarların çoğu yapım sırasında şantiyede olmadıklarından, bazı kararlar onların yokluğunda alınmak zorunda kalır. Yerel malzemeciler ve uygulayıcılar, yeni malzemenin uygulanmasında zorluklarla karşılaşırlar. Bu sebeple yapıların bazıları plana uygun olmayan şekilde bitirilir (Ulmer ve Kurz, 2006, s. 30).

23 Temmuz 1927 tarihinde açılan "die Wohnung" sergisine yapıların büyük kısmı yetiştirilir. Bitmemiş ufak detaylar, Mies van der Rohe tarafından ağustos ayı sonunda tamamlanır.

Weissenhofsiedlung Stuttgart'ın üç parçasından biri olduğu "die Wohnung" sergisi (Şekil 5), 1926 yılında DW'nin Württemberg çalışma grubu tarafından çıkarılan "Yeni Zamanın Konutu" isimli bildiriye dayanmaktadır. "Die Wohnung" [konut] isimli serginin açııısının habercisi olan bu bildiri, artık yeni ve başka bir dünyanın ortaya çıkmış olması gerekçesiyle, insanların yaşayışının yeni konut tipleri ile yeniden organize edilip belirlenmesi gerektiğini ileri sürmekte ve son derece rasyonel bağlamlarda belirlenmiş kriterlere sahip olması gereken konutların özelliklerini sorgulamaktadır. 


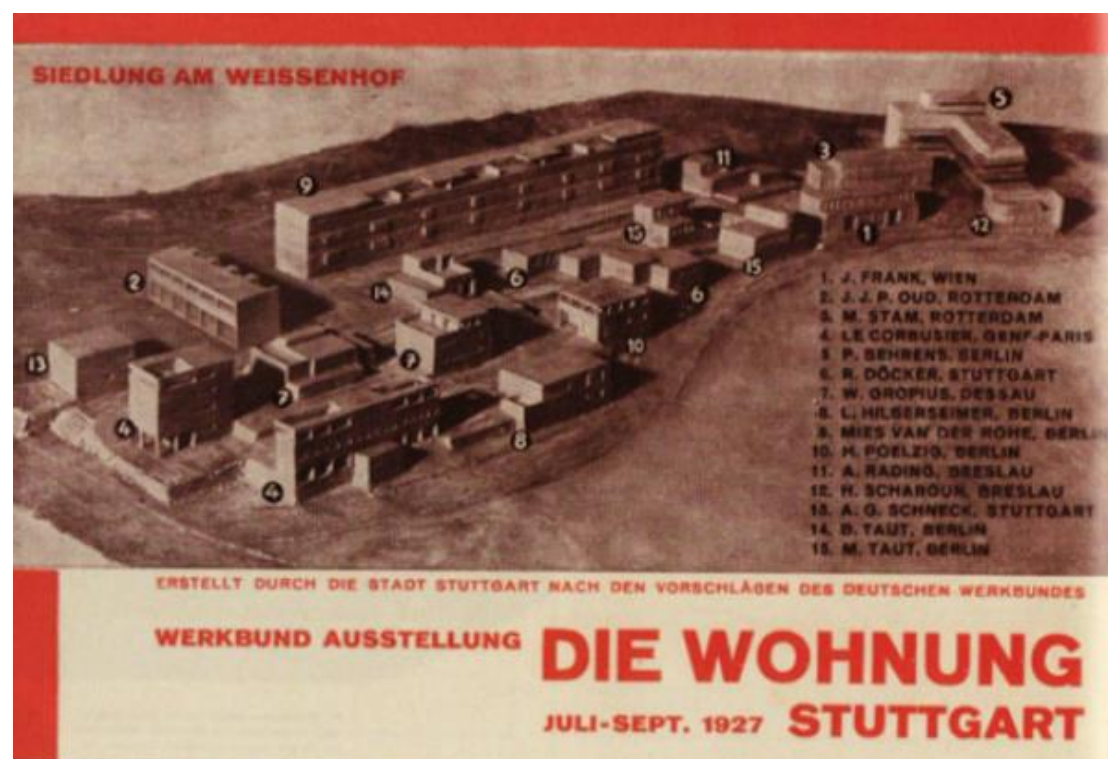

Şekil 5: "Die Wohnung" sergisi afişi (Ulmer ve Kurz, 2006, s. 30)

Üç bölümden oluşan serginin en kritik kısmı; ilk kısmı, serginin açılışına zorlukla yetiştirilen, hatta bir kısmının bitirilişi birkaç ay sonraya ertelenen numune yerleşke, yani Weissenhofsiedlung Stuttgart'tır.

DW, sergiyle birlikte "Bau und Wohnung" ve "Innenraeume" isimli iki kitap çıkarır. Bau und Wohnung'da yerleşkenin tasarımına dahil olan her mimar kendi yapısını bir metinle sunmaktadır. Innenraeume ise yapıların iç dekorasyonundan söz eder. Altmış dört dairenin her biri bütünüyle dekore edilmiştir. Dekorasyonda cam ve seramiğe çokça rastlanır, duvarlarda ise Willi Baumeister gibi ünlü mimarlarının resimleri asılıdır. Yerleşkenin hemen yanında, büyük bir alanda, yeni yapı malzemelerinin, konstrüksiyon biçimlerinin ve yapı makinalarının sergilendiği bir bölüme yer verilmiştir.

"Die Wohnung" sergisi, kapanış tarihi olan 9 Ekim 11927'ye kadar hem Stuttgart hem de Avrupa'nın geri kalanından gelen 500.000'ün üzerinde izleyiciye ev sahipliği yapar. Yerleşke basında da mimari anlamda çoğunlukla olumlu yankı bulmakla birlikte politik bağlamda oldukça eleştirilir. Sol kanat onu sosyal ilerlemeyi yakalayamamakla suçlar; sağcılara göre ise yerleşke yeterince Alman değil, fazlasıyla liberaldir. Muhafazakârlar da yerleşkeyi fazla devrimci ve geleneksek formlara saygısız bulurlar. Yine de Weissenhofsiedlung'da yapılan bu "deney" amacı doğrultusunda oldukça başarılı olur. 1927-1932 yılları arasında Avrupa'nın çeşitli şehirlerinde DW'nin muhtelif kolları tarafından koordine edilen toplam on üç yapı sergisi gerçekleştirilir (Ulmer ve Kurz, 2006, s. 25-33).

"Die Wohnung" sergisinin bitişi ile birlikte yerleşke, Stuttgart kenti yöneticileri tarafından kiralanmaya başlar. Kiralamak isteyen ailelerle, dairelerin mümkün olduğunca orijinalliğinin korunacağına yönelik sözleşmeler imzalanır. Her ne kadar yerleşke, ideolojik bağlamda "herhangi biri" tarafından kiralanabilecek bir alan önerdiği iddiasıyla tasarlanmış olsa da sanatsal değerinden dolayı kiralar çok yüksektir, bu sebeple dairelere çoğunlukla doktorlar, sanatçılar ve benzeri yüksek gelirli kişiler taşınırlar.

Ancak gittikçe yükselen Nazi yönetimi ve Adolf Hitler'in duyulmaya başlayan sesi, Wissenhofsiedlung'un geleceği için hiç de olumlu bir tablo çizmemektedir. 1933 yılında Belediye başkan yardımcısı Karı Strölin, yerleşkeyi "Stuttgart'ın namusuna sürülmüş bir leke" olarak tanımlar ve hemen ardından yaptığı açıklamada "böylesi denemelerin 
önlerinin kesilmesi gerektiği"ni söyler. Yine Stuttgart'ta bir sanat matbaası, Weissenhofsiedlung'u bir Arap köyüne benzeten kolajı basıp dağıtıma sunar. 1928 yılına gelindiğinde yerleşkenin tamamen yıkılması ve yerine büyük bir sanat akademisinin inşa edilmesi kararı çıkar; bu amaca yönelik bir yarışma açılır, hatta Paul Schmitthenner bu yarışmaya karılır. Ancak yarışma sonucu İkinci Dünya Savaşı'nın başlaması ile birlikte uygulanmaz. Mies van der Rohe'nin yerleşke dahilindeki binası savaşta çocuk hastanesi olarak kullanılır. 1942-1945 arasında yerleşke hava saldırılarında zarar görür; Walter Gropius'un tasarımları yerle bir olur, Hilberseimer, Bruno ve Max Taut, Hans Poelzig, Döcker ve Rading gibi mimarların tasarladıkları konutlar yer yer ya da tamamen yok olurlar (Ulmer ve Kurz, 2006, s. 31).

1958 yılında geriye kalan yapılar, korunması gereken sanat eseri statüsüne sahip olurlar. 1981-1987 yılları arasında zarar gören yapılar yenilenir, restore edilir. Yıkılan yapıların yerine yenileri yapılır. Hemen hemen hiçbir yenilemede yapının orijinaline sadık kalınmaz, hatta bir kısım yapıların eğimli çatıları mimarlık çevrelerinde tartışma konusu olur. Yerleşke hala ziyarete açık durumda varlığını sürdürmektedir. Le Corbusier tarafından inşa edilen yapı, müzeye dönüştürülmüştür.

Weissenhofsiedlung'un on yedi mimarının her biri için kendi tasarımları birer yeni çağa ayak uydurma denemesidir. Aslında tek ortak noktaları, geleneksel formları terk etmek olan bu konutlar bütünü, kendini modernist mimarlığın manifestosu olarak ortaya koyarken, çok önemli bir şeyi göz ardı eder: Yeni inşa edilen yapı yapma biçiminin, formdan uzak, rasyonel ve işlevsel olduğunu iddia eden mimarların hemen hepsinin fark etmedikleri şey, Weissenhofsiedlung'un en büyük ortaklığının aslında biçimsel olduğudur. Geleneksel olmayan her form, 19. yüzyıl apartmanlarının muhtelif özelliklerini hatırlatıyor olsa bile modernist kabul edilir. Yani Weissenhofsiedlung'un diliyle modernizm "eski olmayan her şey" şeklinde tanımlanabilir. Bu da yerleşkenin asında tek bir manifestal söylem değil, çoğul katmanlar silsilesi barındırdığının en önemli göstergelerinden biridir.

\section{Kochenhofsiedlung Stuttgart}

Mimarlık tarihi yazımında, Weissenhofsiedlung'un karşıt yerleşkesi, yani bir nevi antitezi olarak geçen ve barındırdığı tüm değer, savunduğu biçem ve işlevsel olgu okumaları Weissenhofsiedlung üzerinden yapılan Kochenhofsiedlung Stuttgart'ın hikayesi aslında Weissenhofsiedlung'unkinden daha katmanlıdır. Modernist ve uluslararası genel geçerlik iddiasındaki mimarlık akımlarının, özellikle İkinci Dünya Savaşı arifesinde modernizmin formatif dönemi sona erip, yerini yükselen ulusalcı anlayışa bıraktığı aralıkta bir ötekilik hikayesi anlatıyor gibi görünse de Kochenhofsiedlung'a daha yakından bakmak ve onu yalnızca Weissenhofsiedlung'un ötekisi olmaktan kurtarıp gelenekselci mimarlık ve bunun yanında geleneksel ve muhafazakâr dünya duruşu bağlamında bakmak oldukça kritiktir.

Olası her literatür taramasında Weissenhofsiedlung üzerinden anlatılan ve dönemin tarihselliğini de aynı bağlamda ikili bir okuma olarak ortaya çıkmasına neden olan Kochenhofsiedlung Stuttgart, aslında çok fazla pratiğin bir araya gelmesi ile mevcut olmuş özgül bir durum olarak görülmelidir.

Bunu şu şekilde açmak mümkün: Kochenhofsiedlung Stuttgart, her ne kadar kâğıt üzerinde Weissenhofsiedlung Stuttgart'ın tartışmaya açtığı ve okunabilir kıldığı her değerin tam tersini söylüyor gibi görünse de tarihsel olaylar, durumun biraz daha farklı geliştiğinin kanıtlarını sunmaktadır. Öncelikle Kochenhofsiedlung'un politik darbeler, şanssızlıklar ve tesadüflerle dolu inşa edilme hikayesinde DW ve ünlü yönetici-mimarı 
Richard Döcker'den Kochenhofsiedlung'un uygulayıcısı olarak tarihe geçen Paul Schmitthenner'e, Alman Orman Bakanlığı'ndan yükselen nasyonal sosyalist yönetimi aktörlerine kadar birçok kurum ve kişinin adı geçmektedir. Bu da yerleşkenin, oluştuğu ana kadarki planlama sürecinde farklı şekillerde katmanlaşma ve dönüşümlerin yaşandığı anlamına gelmektedir.

Kochenhofsiedlung'un inşa edildiği 1933 yılına gelindiğinde mimarın rolünün üstlendiği "toplum mühendisliği" görevinden "ulus mühendisliği"ne terfi ettiğini vurgulamak önemlidir. Nasyonal sosyalistlerin yönetime gelmesiyle birlikte "toplum"un yerini "ulus"a bırakması kaçınılmaz bir olgu olarak karşımıza çıkar. Paul Bonatz tarafından yönetilen Stuttgart Okulu çevresinde toplanan muhafazakâr mimarlar, yüzlerini uluslararası olandan ulusal olana çevirirler, elbette ulusal olan da yeni resmî ideoloji bağlamında tekrar tanımlanacaktır. Bu noktada işin içine başka kavramlar girer. Uluslararası Üslup kendini zamanın ruhu [Zeitgeist] olarak tanımlarken Stuttgart Okulu çevresinde biriken hiç de azımsanmayacak sayıdaki entelektüeller, Zeitgeist'ın yerine Volkgeist'ı yani halkın ruhunu koyarlar. Halk Alman halkıdır ve onun bağlamında üretilecek her mimarlık ve sanat eseri de aynı derecede Alman olmak zorundadır. Yeni Mimari anlayışının evrensellik söylemlerinin karşısında olmakla birlikte, zamanın ruhunu vücuda getirmeye çalışan, hatta güncel teknikleri ve malzemeyi mimarlık pratiğinin merkezine yerleştiren tüm modernist söylemlere kendini alternatif olarak sunan bu damar, mimarlığı "kan ve toprak" [Blut und Boden] ile ilişkilendiren, dolayısıyla ulusal aidiyet ve kimlikli bir üretimi savunan ulusalcı bir tahayyüle işaret eder.

Bir yandan Yeni Mimari veya modernist mimarlığın evrensel ve zamansız mimarlık hayallerinin tüm sorunsallarından arınmış gibi gözüken Alman ulusalcı mimarlığı, öte yandan disiplini farklı bir kavramsal çerçeve içerisinde ve çok daha tehlikeli bir güzergahtan paketlemekte ve kapatmaktadır: Mimarlık yöreye ait olmalıdır, çağın değil "yer"in ve "halk"ın ruhu vardır, güncel teknik ve malzeme değil geleneksel yöntem ve ürün hayati olandır. Dolayısıyla mimarlık, modern aklı neredeyse hiçe sayarak premodern pratikleri üzerinden gerçekleştirilmelidir ki "öz"ü kaybedilmesin.

İşte tüm bu tahayyüllerle ilişkilendirilerek inşa edilen ve daha sonra milliyetçilikle örüntülü bir şekilde nerdeyse bir manifesto niteliğine erişen bu yerleşkenin, Weissenhofsiedlung'un içinde barındırdığı çoğulluğa sahip olmamasının birçok sebebi mevcuttur. Çoğulluğun karşısında hemen hemen tüm konutları birbirinin aynısı olarak inşa edilen Kochenhofsiedlung öncelikle ve ısrarla geleneksel dünya ile bağlantısını koparmaz. Kaldı ki yerleşkenin mimarları, Weissenhofsiedlung konut grubunun mimarlarının sorduğu soruların hepsini es geçerken geleneksellik ya da gelenekselcilik ilüzyonu altında yalnızca tek bir şekilde inşa edilebileceği hayalini uygulamaya koyma çabası içine girerler. Yerleşke inşa edilirken tasarımcılara şart koşulan onlarca kısıtlamadan yalnızca bir tanesi, konutlarda kırma çatı kullanma zorunluluğudur. Bunun yanında programda; ahşap cephelerin sıvanması ya da dokuyu gizleyecek şekilde boyanması gerekliliği yer almaktadır. Aynı zamanda ısı ve ses kontrolleri bağlamında da birçok kısıtlama mevcuttur. Ne var ki, aslen yapı sektörüne mensup aktörleri, ahşap yapıların ekonomikliği ve uzun ömürlülüğü konusunda ikna amacı güdülen Kochenhofsiedlung'un oluşturulma hedefleri arasında Schmitthenner'in vurguladığı başka bir madde daha yer alır: ahşap yapı teknikleri, ancak geleneksel deneyimleri temel alarak geliştirilebilir. Bu tandansa, ironik kabul edilebilecek bir biçimde; yapıların servis hizmetlerini belirleyecek teknik gerekliliklerin çağdaş standartları yakalamaları gerektiği ilave edilir.

Kochenhofsiedlung'un kavramsal ortaya çıkış ve morfolojik bağlamda imal edilişini özellikle Paul Schmitthenner üzerinden okumaya çalışmak önemli gözüküyor. 
Yukarıda değinmiş olduğumuz üzere içine birçok aktör karışan ve türlü başka söylemlerle katlanarak çoğullaşmakla birlikte hemen hemen birbirinin aynısı konutların üretilmesiyle sonlanan Kocehnhofsiedlung'un aslında bir anlamda Paul Schmitthenner'in mesleki intikamına dönüştüğünü söylemek mümkündür. Mimarlara getirilen söz konusu kısıtlamalar, Mies van der Rohe'nin, yönetici mimar olarak Weissenhofsiedlung'un tasarım ve uygulama sürecinde yürüttüğü uygulamanın tam tersidir; bu durum da başlı başına tekil tasarımların önünün açılmasını zorlaştırmaktadır. Bir başka nokta, Schmitthenner'in 1927 tarihinde bir deneme olarak, öngörülmüş ancak asla hayata geçirilmemiş Kochenhof sergisi için yaptığı tasarım, çizim ve numuneleri Kochenhofsiedlung'un seçilmiş mimarlarına örnek olarak sunması, bir anlamda dayatmasıdır. Dolayısıyla Schmitthenne'in Kocehnhofsiedlung'u, Bonatz'ın arka plandan destek verdiği tek kişilik bir şov gibi algılanabilir.

Dönemin politik dinamikleri dahilinde nasyonal sosyalistlerin gittikçe güçlendiği ve onların topluma dair tahayyüllerinin mimari karşılığını Kochenhofsiedlung'un kavramsal uzantısında bulmalarından dolayı Schmitthenner'e destek vermeleri gözden kaçırılmaması gereken bir diğer unsurdur. Kaldı ki bu durum, Kochenhofsiedlung'u Orman Bakanlığı destekli basit bir ahşap sergisi ve ahşap evler yerleşkesi olmaktan çıkartıp, onu ideolojik bir Alman Kültürü kavgasına dönüştürmektedir.

Kochenhofsiedlung'u ortaya çıkartan karmaşık politik, ekonomik ve sosyal örüntülerin çözümlenmesi, onu yalnızca bir "Anti-Weissenhofsiedlung" olmaktan kurtararak, kendi özgül olgularını gözler önüne serecek görece tarafsız bir okuma yapabilmenin yolunu açar. Yerleşkenin önemini kendi içinde kavramak ve dönem mimarlarının ve politikacıların ilişkilerinin bağlamını yerleşke özelinde ortaya koymak oldukça önemlidir.

1927 yılı ocak ayında dönemin Belediye Başkanı Daniel Sigloch, resmi olarak, Berlin'den iki sergi/yerleşke için bütçe alınacağını duyurur. Bunlardan biri, zaten halihazırda iki yıldır hazırlıkları süren Weissenhofsiedlung ve "Die Wohnung" sergisidir. İkincisi için ise hemen çalışmalara başlanması gerekmektedir.

Söz konusu ikinci sergi için arazi aranmaya başlar ve sürecin sonunda Weissenhofsiedlung'un konumlanacağı bölgenin oldukça yakınında ve "Am Kochenhof" isimli caddenin hemen bitişiğindeki alanda karar kılınır. Sergi/yerleşkenin adı "Versuchsiedlung am Kochenhof" [Kochenhof'ta Deneme Yerleşkesi] olarak belirlenir. Bu deneme yerleşkesinin amacı; farklı büyüklükteki konutlar için en iyi ekonomik, teknik ve sosyal çözümün saptanması olmalıdır (Ulmer ve Kurz, 2006, s. 222). Zaten alıntıladığımız bu cümlede geçen her madde, Schmitthenner'in Weissenhofsiedlung özelinde eleştiri yağmuruna tuttuğu unsurlardır.

Schmitthenner, Kochenhof'ta yapılması planlanan yerleşke le ilgili vakit kaybetmeden çalışmaya başlar; kullanılacak malzemeleri ve tasarlanacak konutların büyüklüklerini belirler. Bu konutlar, tek aile evinden, sekiz ailenin yaşayabileceği büyük birimlere kadar değişiklik göstermektedir. Aynı zamanda programa ortalamanın altında kazancı olan ve toplumun alt seviyesinde yer alan aileler için "Kleinwohnungen unter dem sozialen Minimum" [Sosyal Minimum'un Altındaki Küçük Konutlar] dahil edilir (Plarre, 2001, s. 32).

Schmitthenner yaptığı işi "rasyonel mimarlık arayışı" olarak meşrulaştırır ve bu şekilde savunur. Yapı elemanlarını biçimleri ve özellikle çatılar yerleşke bağlamında öne çıkan tartışma konuları olarak belirir. 
Weissenhofsiedlung Stuttgart'ın inşa edilmekte olduğu bu dönemde özellikle Mies van der Rohe ve Walter Gropius'tan oluşan karşıt grup, Schmitthenner'in planı ile ilgili görüşlerini belirtmekten çekinmez. Gropius, Schmitthenner'in tasarımlarının güncel metotlarla hiçbir şekilde uygulanamayacağını öne sürer ve onları eski ve modası geçmiş olmakla suçlar (Plarre, 2001, s. 26).

Ancak devletin üst kademelerinde Schmitthenner'in tasarımları ve planı çok beğenilir. Hem geleneksel değerleri savunduğu söylenen hem de yükselen yeni mimarlığın yöntemlerine uygun olduğu düşünülen bu yerleşkenin inşası mutlak surette istenmektedir. Bu süreç boyunca başka hiçbir mimarın ismi ön planda olmadığı için söz konusu deneme yerleşkesi "Versuchsiedlung Schmitthenner" olarak anılmaya başlanır (Ulmer ve Kurz, 2006, s. 177-187).

Schmitthenner bu süreçte muhtemelen oldukça politik davranmıştır. Zira 1922 yılına gelindiğinde konutların yalnızca belli bir gelir seviyesinin üzerindeki aileler için tasarlanması gerektiğini ileri sürecek ve Alman Evi'nin özelliğinin üst düzeydeki Alman Halkı'nı barındırması olduğunu söyleyecektir.

Ekim 1927'de yerleşkenin yapılmasına kesin olarak karar verilir. 1928 yılı mart ayına kadar toplam 136 daire içeren otuz konutun tasarlanması ve inşaatın mayıs ayı başında başlaması uygun görülür.

Lakin söz konusu kararların alınması tam olarak "Die Wohnung" sergisinin bitişine denk gelmektedir. Serginin dünya genelinde çok büyük bir yankı uyandırmış olması sebebiyle, Kochenhofsiedlung için düşünülen alanın boş bırakılmasına karar verilir. Böylece Weissenhofsiedlung'un büyütülmesine karar verilirse bu alandan faydalanabilmesinin yolu açılmış olur (Ulmer ve Kurz, 2006, s. 178).

Kuşkusuz mimari anlayışı geleneksellik ve onun periferisindeki yan değerler; yani yere uygunluk, iklim ve coğrafyanın üzerine kuran Paul Schmitthenner için arazinin değişmesi oldukça uygusuz bir durumdur. Belediye başkanlığı ve valilik Schmitthenner'in tasarım ve fikirlerini hala desteklemektedirler, ancak Weissenhofsiedlung Stuttgart ve çerçevesinde düzenlendiği "die Wohnung" sergisi, yüzyıl başında Avrupa'da yaşanan en büyük mimari ve sanatsal olay olarak kabul edilmiştir ve kimse bu başarıya gölge düşürmek istememektedir. Schmitthenner'in tasarımları için hızla yeni bir arazi arayışına girişilmiş olsa da mimar, araziye karar verenin kendisi olması gerektiğini ve bu konuda tam yetki istediğini ifade etmiştir.

Oysa Schmitthenner bu resmî açıklamasını yaptığında belediye başkanlığı, yeni araziye çoktan karar vermiş bulunmaktadır. Arazi Hallschlag'da yer almaktadır ve yerleşkenin adı "Ersatzsiedlung im Hallschlag, 1928" olarak belirlenmiştir.

Karşı karşıya kaldığı bu durum, Schmitthenner için elbette kabul edilebilir değildir. Belediye başkanlığı ile tekrar yazışarak yerin değişmesini ve kararın kendisine ait olmasını yeniden talep eden Schmitthenner isteğine olumsuz yanıt alınca söz konusu projeyi yürütmekten vazgeçer. Durum, ikinci yerleşke fikrinin bir süreliğine rafa kalkmasıyla sonuçlanır (Plarre, 2001, s. 92).

1932 yılının sonuna gelindiğinde, Schmitthenner'in daha önceki planlarından bağımsız olan başka bir sergi ve yerleşke fikrinden söz edilmeye başlanır. Almanya'daki orman ve ahşap endüstrisinin ekonomik durumunun güçlenmesi için ortaya atılan bu sergi fikrinin amacı, Yeni Mimari ile gündeme taşınan yeni malzemeler [cam, ahşap, metal vb.] yerine geleneksel Alman mimarisinde kullanılan en önemli malzeme olan ahşabın inşaat 
sektörüne yeniden kazandırılmasıdır. Ahşabın eski gelenekselci Alman mimarlık biçemlerine uygunluğu kadar yeni yapı sanatının uluslararası formlarıyla da olumlu ilişki kurabileceğinin gösterilmesi amaçlanan bu sergi ve yerleşkenin baş aktörü, 1927 tarihinde Weissenhofsiedlung Stuttgart yerleşkesi ve "die Wohnung" sergisinde olduğu gibi, DW Württemberg grubu ve grup başkanı Gustav Stotz'dur. Serginin adı ise "Deutsches Holz für Hausbau und Wohnung, Werkbund-Ausstellung Stuttgart, 1933" olarak belirlenmiştir.

Sergi alanı ve yerleşke arazisi olarak 1927 yılı sonunda tartışılmaya başlanan Weissenhofsiedlung yakınındaki Kochenhof alanı yeniden gündeme gelir ve resmi olarak onaylanır. DW Württemberg grubu hızla proje üzerinde çalışmaya başlar.

Projenin temel esasları çabucak belirlenir: ağırlık verilmesi gereken konu, Almanya'nın ormana dayalı ekonomisinin ve ahşap üretiminin hızlanmasıdır. Bu da ahşabın yapı sektöründe tekrar eski önemine kavuşması anlamına gelmektedir. Aslında bu durum, DW'nin Almanya ulusu ve devleti inşası görevi ve söz konusu ulusal değerlerin uluslararası arenaya taşınmasındaki rolü açısından bakıldığında oldukça kritiktir. Lakin, Alman mimarisinin uluslararası arenada yarışması; Alman kanının aktığı yerde ve Alman coğrafyası ile örtük bir ilişki içerisinde olması beklendiği için, kavramsal olarak hatalıdır. Zira, çağın nabzını tutan yeni biçemler ve Yeni Mimari artık başka kriterlerle tanımlanmaktadır. Burada karşılaşılan katmanlı sorunsalın çıkış noktası, Kochenhofsiedlung girişimcileri tarafından, yeni formlarda ahşabın kullanılması şeklinde çözülmeye çalışılacaktır (Şekil 6).

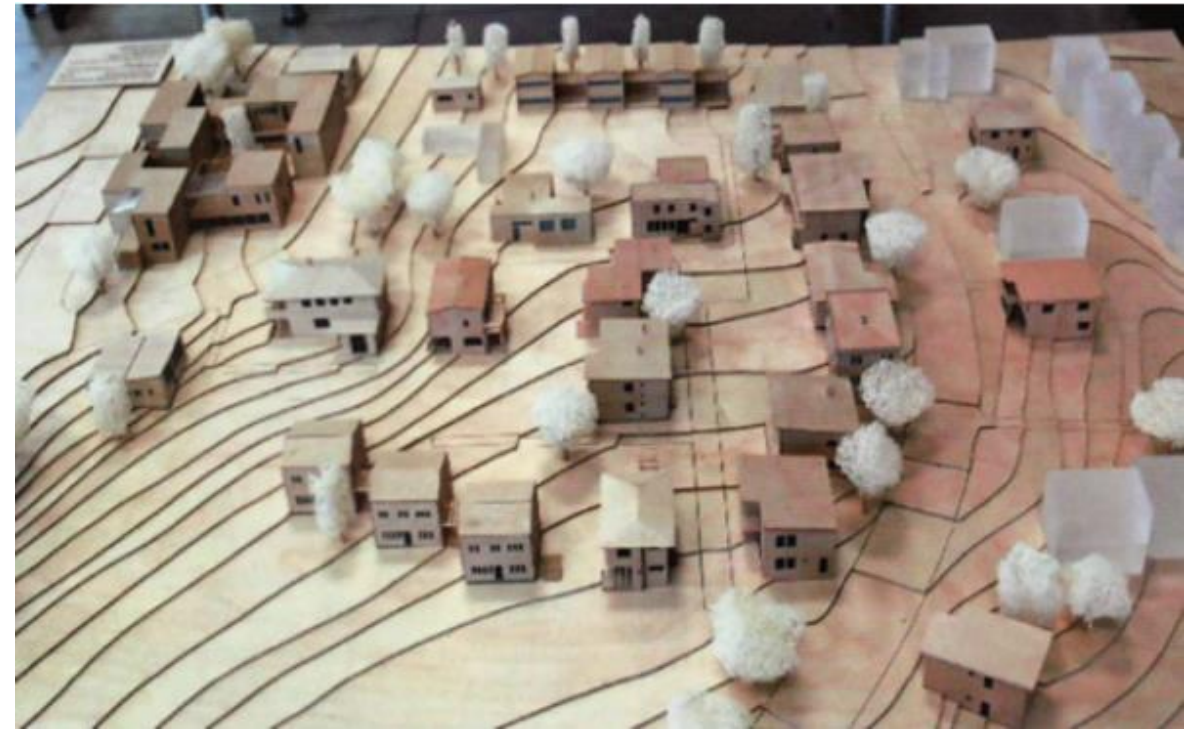

Şekil 6: Kochenhof yerleşkesi maketi (Ulmer ve Kurz, 2006, s. 178).

Proje yöneticiliğine Richard Döcker getirilir; vaziyet planı da kendisi tarafından yeniden oluşturulur. Kısa süre içerisinde yerleşke tasarımına iştirak edecek mimarların isimleri şu şekilde belirlenir: Carl Caspary, Stuttgart; Richard Döcker, Stuttgart; Kurt Friedberg, Stuttgart; Hugo Haering, Berlin; Richard Herre, Stuttgart; Lucy Hillebrand, Mainz; Kugo Keuerleber, Stuttgart; Walter Körte, Stuttgart; Franz Krause, Berlin Eduard Krüger, Stuttgart; Werner M. Moser, Zürih; Oskar Pfennig, Stuttgart; Adolf G. Schneck, Stuttgart; Rudolf Steiger, Zürih; Konrad Wachsmann, Berlin; Ernst Wagner, Stuttgart; Hellmut Weber, Stuttgart; Hans Zimmermann, Stuttgart (Plarre, 2001, s. 26). 
$\mathrm{Bu}$ isimlerden bir kısmının adı, yukarıda belirttiğimiz üzere Weissenhofsiedlung Stuttgart'ta da geçmektedir; bu da vaziyet planının ortaya konmuş maketinde neden yine teras çatılar, kübik biçemler ve süssüz, yalın cepheler bulunduğunu açıklayabilmek adına önemli bir ipucudur. Yapılar tamamen ahşaptan tasarlanmışlardır, ancak yeni zamanın formlarına sahiptirler. Döcker "ahşap evin şehirdeki halini" tasarlamak istediklerinden dem vurmaktadır; amaç da şehirde yaşayan halkın taleplerine uygun biçimde zamanın konutunu ortaya çıkartabilmektir (Plarre, 2001, s. 32). Bu durum, bir anlamda ahşabın "yerinden edilmesi" olarak yorumlanabileceği için; yeni formlar ile geleneksel malzemenin birleşmesi o güne kadar görülmemiş bir durum ortaya çıkardığından, söz konusu yerleşke tahayyülü yine başta Paul Schmitthenner, Paul Bonatz ve Stuttgart Okulu olmak üzere sağ kanattan çok fazla eleştiri alır (Plarre, 2001, s. 42). Hatta Schmitthenner 1933 'e tarihlenen eleştirel makalelerinde, Kochenhof'taki yerleşke tasarımının "sürekli bir aptallıktan" ibaret olduğunu yazmakta hiçbir çekince görmeyecektir (Plarre, 2001, s. 26).

Yükselen nasyonal sosyalizm ile değişen yönetim kadrolarının örneklerinden biri de Württemberg eyaletinin belediye başkanlığına, doğrudan partiden atanan Karl Strölm'dür. Yeni milliyetçi yönetim, DW'nin sergi ve yerleşke planlarını rafa kaldırmakta gecikmez. Paul Schmitthenner de hızla bu fırsatı değerlendirir; daha önce önermiş olduğu sergi ve yerleşke konseptini yeniden dolaşıma sokar. Önce Paul Bonatz ile yaptığı titiz çalışmanın ardından proje yürütücülüğüne Heinz Witzel'i getiren ve ardından kendi mimar kadrosunu belirleyen Schmitthenner, proje için önerilecek 25 konutun tasarımcıları arasına başta kendisi olmak üzere şu isimleri dahil eder: Paul Bonatz, Friedrich Eugen Scholer, Ernst Schwaderer, Paul Heim, Hermann Gabler, Hans Volkart, Gerhard Graubner, Richard Weber, Eugen Kiemle, Paul Weber, Albert Eitel, Hans Eitel, Alfred Kircherer, Eduard Krüger, Otto Köbele, Eisenrohr \& Pfenning Mimarlık Bürosu, Hellmut Weber, Walter Körte, Ernst Wagner, Ernst Leistner, Werner Pilzecker, Hans Mayer, Erhard Rommel, Erich Wiemken, Wilhelm Tiedje, Karl Gonser (Plarre, 2001, s. $55)$.

Çoğu Stuttgart Okulu kökenli bu isimler aracılığıyla inşa edilecek yerleşkenin başlama tarihi 1933 Mayıs ayı olarak belirlenir. Schmitthenner'e göre Weissenhofsiedlung ve "Die Wohnung" nasıl bir modernist konut ve yeni bir yaşam biçimi manifestosu teşkil ediyorsa, Kochenhofsiedlung ve beraberindeki sergi de Alman geleneksel ve milli değerlerini yansıtan bir manifesto olarak tanımlanmalıdır. Projenin adı kısa süre içinde, Schmitthenner tarafından önerildiği haliyle "Kampfbund für deutsche Kultur" olarak telaffuz edilmeye başlanır (Plarre, 2001, s. 62).

Serginin adı ise "Deutsches Holz für Hausbau und Wohnung, Stuttgart 1933" olarak belirlenir. Projenin yaklaşımlarından bir diğeri, bu yerleşkede proletarya konutlarına yer verilmesinin imkânsız olduğu, konutların yalnızca en üst düzey Alman aileler için tasarlanacağı önermesidir (Ulmer ve Kurz, 2006, s. 177-187).

Yalnızca birkaç ay içerisinde tamamlanan ve 1933 yılının sonlarına doğru ziyaretçiye açılan Kochenhofsiedlung, yapıların iç mimarlığı ve dekorasyonu ile de görücüye çıkar. Kurgu olarak Weissenhofsiedlung Stuttgart ile benzer bir paralellik gösteren Kochenhofsiedlung da numune bir yerleşkedir; bu özelliğe konutların dışı olduğu kadar içi de dahildir. Çoğu konuttaki mobilya üretme işi Paul Bonatz tarafından üstlenilmiştir; mimarın Alman ahşabının geleneksel kullanımdaki önemini gözler önüne sermek için verdiği uğraş oldukça çarpıcıdır (Plarre, 2001, s. 62). Bunun yanında yerel, bölgesel ve genel yönetimi arkasına almış olan Schmitthenner'in sergi ve yerleşkesinin açılışında nasyonal sosyalist bayraklara yer verilmiş olması, oldukça dikkat çekici başka bir detay 
olarak karşımıza çıkar (Ulmer ve Kurz, 2006, s. 177-187). Plarre, söz konusu durumu, temsiliyetin gücü olarak adlandırır (Plarre, 2001, s. 57).

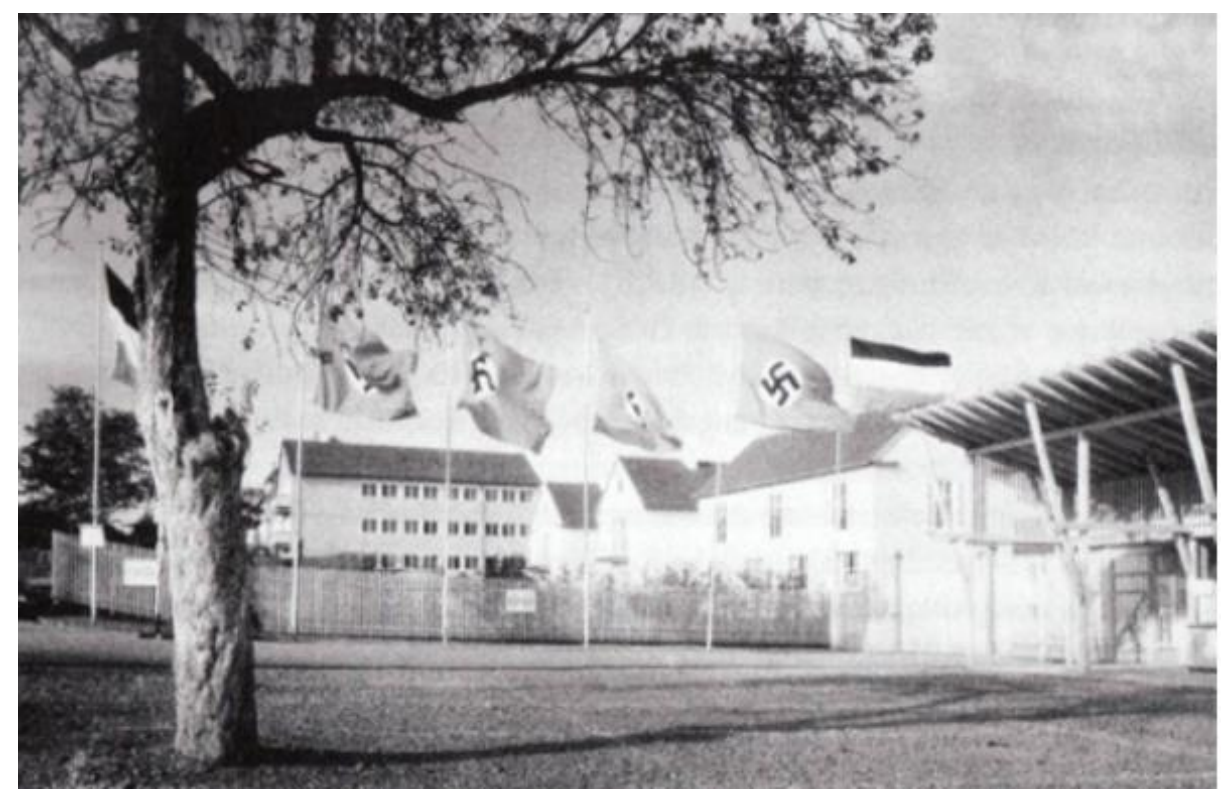

Şekil 7: Kochenhofsiedlung (Plarre, 2001, s. 12)

Kochenhofsiedlung üzerinden rahatça okunabilen düzen ve uyumun başlıca sebeplerinden birinin, tasarımlara çizilen katı çerçeveler olduğunu söylemek mümkündür. Mimarlar tarafından tamamen ahşap strüktür kullanılarak inşa edilmesi beklenen yapılar aynı zamanda kırma çatılı olmalıdır. Yine ahşap olacak cepheler ya sıvanmalı ya da ahşap dokuyu gizleyecek şekilde boyanmalıdır, ki bu da karşımıza çözümlenmesi gereken bir diğer sorunsal şeklinde çıkar. Aynı zamanda ısı ve ses korunumu açısından da ortaya konmuş sayısız gereklilik, Schmitthenner ve Bonatz tarafından, yarışmanın şartları arasına dahil edilmiştir (Plarre, 2001, s. 65) (Şekil 7).

Akıbeti, İkinci Dünya Savaşı sebebiyle Weissenhofsiedlung'dan pek farklı olmayan yerleşkenin bir kısmı yerle bir olur. Sol eğilimli sanat ve mimarlık çevreleri tarafından "Holzwurmsiedlung" şeklinde dalga geçilmesine rağmen, Kochenhofsiedlung nasyonal sosyalist tarafından yüceltilmiş, ona tüm temsiliyetler bağlamında yüksek değerler atfedilmiştir (Plarre, 2001, s. 75).

\section{Sonuç}

Weissenhofsiedlung Stuttgart, üzerinden mimarlığın formatif olarak tanımlanan erken modernist dönemine dair müthiş bir okuma yapılmasına olanak sağlayacak kadar çoğul bir içeriğe sahiptir.

Bu durum yalnızca, yerleşkede dönemin "Uluslararası Üslup" adına üretim yapan en önemli isimlerinin [Le Corbusier, Walter Gropius, Mies van der Rohe] rol almış olmalarından kaynaklanmaz. Gesamtkunstwerk kavramı ile adı bir arada anılan kişilerin [Peter Behrens] isimlerinin yerleşkede geçiyor olması da bunun yegane sebebi değildir. Weissenhofsiedlung'un Kochenhofsiedlung Stuttgart'ın "öteki” yerleşkesi olarak tanımlanması ve bunun üzerinden Paul Schmitthenner ve Stuttgart Okulu'nun gelenekselci ideolojilerine uzanan yol da bu durumu tek başına açıklamaya yetmez. 
Weissenhofsiedlung'un durumunu eşsiz kılan olgu, yerleşkenin, içerisinde bir yandan morfolojik ve ideolojik olarak bunca çoğulluk ve farklılık barındırırken diğer yandan "Modernist Konut manifestosu" olarak mimarlık tarihi yazımında yer almasıdır. Mimarlık tarihi yazımı, yapıldığı dönemde bir ulus inşa etmeye yönelik çabalarıyla Weissenhofsiedlung'a çağın ve ulusun kültürel pratiklerini temsil etme görevi yükleyen Deutscher Werkbund'un açtığı yolu izleyerek yerleşkenin üzerine Modernist Mimarlık örtüsünü çeker ve bu durum yerleşkenin aynılık ürettiği yanılsamasının doğmasına yol açar.

Ancak tam olarak da bu durum erken modernist dönemin formatifliğine dair müthiş bir okuma yapma olanağı verir. Modernist mimarığın formatif dönemi, bu dönem yapılan tüm mimari üretimleri geleneksel mimarlık üretiminden ne kadar ayrıldığına göre sınıflandırır. Bu durum da üzerinde geleneksel herhangi bir süsleme taşımayan her yapının Modernist olarak tanımlanmasıyla son bulur. Bu, üslubu işlev üzerine inşa ettiklerini savunan mimarların ideolojileri dikkate alındığında oldukça ilginç bir durum olarak ortaya çıkar. Çünkü biçimin işlevi izlemesi gerektiği yerde, formatif dönemde işlev dikkate alınmaksızın tüm üretimler Modernist Mimarlık Üretimleri olarak lanse edilir.

Bu durumun işaret ettiği ilk olgu, modernitenin fragmanlaşan dünyasının göstergesidir. Weissenhofsiedlung Stuttgart mimarlarının hepsinin kendi kafalarındaki küçük ya da büyük merkez tanımları, yerleşke kapsamında vücut bulur. Bu da her yapının ideolojik ve morfolojik olarak birbirinden farklı sonuçlar doğurmasına yol açar. Ancak bu kadar küçük ve farklı merkez tanımı da çoğulluk ve farklılıkları itibariyle tehlike içerdiğinden Modernizm örtüsü altında birleştirilir, tüm farklılıklar eritilit, tüm çoğulluklar ortadan kalkar ve Weissenhofsiedlung Stuttgart'ın biçimsel ve ideolojik analizinin yapılması olanaksızlaşır. Bu şekilde ne mimarların üretim biçimlerini ne de yapıların, kullanılan malzeme, işlev ve yapım tekniği bağlamında ortaya çıkan sonuçlarını anlamak mümkün olur. Weissenhofsiedlung Stuttgart aynılık üreten bir illüzyon olarak mimarlık tarihi kitaplarındaki yerini alır.

$\mathrm{Bu}$ durum Modernist Mimarlığın ne çeşit bir karşı-modern anlatı olduğunun ve gelenekselci mimarlıktan çok daha büyük bir kapalııı içerdiğinin çok önemli bir kanıtıdır. Başka bir olgu, Weissenhofsiedlung Stuttgart'a Deutscher Werkbund tarafından yüklenen temsiliyet rolünün üretim sırasında yumuşaması, erimesi ve yerleşkenin aynılık yerine farklılık üretmesidir. Bu, modern dünyada ortaya çıkan kültürel pratiklerin tüm kapatmalara rağmen sızdırdığının göstergesidir. Bu da yine dönemi anlamak adına yapılmış önemli bir okumadır.

Weissenhofsiedlung Stuttgart'ı gerek morfolojik ve ideolojik çoğullukları gerekse Kochenhofsiedlung'un karşıtlığı bağlamında anlamak dönemin mimarlık üretimini anlamanın yolunu açar. Bu durum da dönem okumasının objektif bir biçimde yapılmasına olanak sağlar. Yerleşkeyi anlamak bu açıdan çok önemlidir. Günümüzün kültürel pratikleri, her zaman olduğu gibi yalnızca farklılık ve çoğulluk üretirler. Weissenhofsiedlung Stuttgart, böyle bir okuma yapmanın önünü açmış bulunmaktadır.

\section{Kaynaklar}

Berman, M. (1988). All That Is Solid Melts Into the Air: the Experience of Modernity. New York: Viking Penguin.

Bonatz, P. (1926). Noch einmal die Werkbundsiedlung. Schwaebische Kronik, 2, 4.

Giedion, S. (2001). Space, Time \& Architecture The Growth of a New Tradition. London: 
Harvard University Press.

Kirsch, K. (1997). Briefe zur Weissenhofsiedlung. Stuttgart: Deutsche Verlags-Anstalt.

Le Corbusier. (2005). Bir Mimarlığa Doğru. İstanbul: Yapı Kredi Yayınları.

Loos, A. (1998). Ornament and Crime. Ornament and Crime: Selected Essays (pp. 3955). Riverside: Ariadne Press.

Maciuika, J. (2009). The Deutscher Werkbund and the Ottoman Empire: Design Reform, Economic Policy and Foreign Policy Before the First World War. Modernleşmenin Tasarımı Türkiye'de Mimarlık, Sanat, Tasarım Eğitimi ve Bauhaus (pp. 67-79). İstanbul: İletişim Yayınları.

Merzi, S. (2005). Çevirmenin Önsözü, Bir Mimarlığa Doğru (pp. 9-13). İstanbul: Yapı Kredi Yayınları.

Plarre, S. (2001). Die Kochenhofsiedlung-Das Gegenmodell zur Weissenhofsiedlung. Stuttgart: Hohenheim.

Schwartz, F. (1996). The Werkbund Design Theory and Mass Culture Before the First World War. London: Yale University Press.

Ulmer, M., \& Kurz, J. (2006). Die Weissenhofsiedlung Geschichte und Gegenwart. Stuttgart: Hampp Verlag.

Wikipedia. (2021). Peter Behrens. Retrieved from

https://www.google.com/search?q=peter+behrens+aeg\&client=safari\&rls=en\&source=1 nms\&tbm $=$ isch\&sa $=X \&$ ved=2ahUKEwiTuqfiv9LwAhUS-

aQKHUsmAa8Q_AUoAXoECAEQAw\&biw=1564\&bih=1333

Erişim tarihi: $10.03 .2021,15.00$. 